\title{
When and Why Do Venture-Capital-Backed Companies Obtain Venture Lending?
}

\author{
Tereza Tykvová*
}

\begin{abstract}
I model the decision of an informed early-stage venture capital (VC) investor that considers involving an uninformed $\mathrm{VC}$ or venture lending (VL) investor to finance the late stage. Early-stage VC investors that own high-quality value companies tend to signal their quality and they frequently turn to VL investors. Early-stage VC investors prefer VC if the proportion of high-quality companies in the population is high, if their companies have a high upside potential, if they can benefit from the value that late-stage $\mathrm{VC}$ investors add, or if uncertainty is high. I find empirical evidence consistent with these predictions.
\end{abstract}

\section{Introduction}

Although young entrepreneurial companies with uncertain future prospects seem to be poor candidates for debt financing, recent empirical evidence suggests that these companies often receive loans, in combination with equity or equity-like financing (e.g., Cosh, Cumming, and Hughes (2009), Cumming (2005), and Robb and Robinson (2014)). Despite the importance of venture lending (VL), there is not much theoretical research investigating the forces that shape it. In view of this gap in the literature, the aim of this article is to contribute to our understanding of the reasons behind lending to young entrepreneurial companies with uncertain future prospects. In the first part of the article, I build a theoretical model to examine how informed early-stage venture capital (VC) investors decide whether to turn to either equity investors or debt investors to finance their portfolio companies whose prospects in the late stage are uncertain. The model helps explain when and why VC-backed entrepreneurial companies obtain VL to fund their business growth instead of raising a new round of equity. I also examine how the possibility of

*Tykvová (corresponding author), tereza.tykvova@uni-hohenheim.de, Institute for Financial Management, University of Hohenheim. I am thankful to Douglas Cumming (the referee), Paul Malatesta (the editor), and the participants of the 2015 Financial Management Association European conference and the 2014 Paris Financial Management conference for their comments. I gratefully acknowledge access to Dow Jones Venture Source, Bureau van Dijk Orbis, Standard \& Poor's Capital IQ, Thomson ONE, and Datastream provided by DALAHO, University of Hohenheim. I thank Tim Pollock for providing me with the data on VC reputation. Julia Stefanchuk and Urs Schopp-Leypoldt provided invaluable assistance during the data-collection phase. All errors are my own. 
obtaining VL in the late stage affects the availability of early-stage VC financing. From my theoretical model, I derive predictions related to the use of VL and test them in the second part of the article. To test my predictions, I use an extensive novel data set of more than 50,623 debt and equity financing rounds in 12,629 VC-backed companies based in the United States from 1995 to 2013.

Existing research on VL typically focuses on case investigations (Crawford (2003), Hardymon and Leamon (2001), Hardymon, Lerner, and Leamon (2005), and Roberts, Sahlman, and Kind (2008)) or data gained from interviews (Fischer and de Rassenfosse (2013), Ibrahim (2010)). According to these studies, VL first appeared in the United States in the 1970s (see Hardymon et al. (2005)) and has developed into a sizable industry with institutions, such as Silicon Valley Bank, that specialize in providing loans to entrepreneurial companies that traditional banks turn away (see Ibrahim (2010)). Fischer and de Rassenfosse (2013) estimate that the size of the VL industry in the United States reached US\$3 billion in 2010, which amounts to about $13 \%$ of the VC industry in the United States. The proportion in the sample I use for this study is similar: $15.9 \%$ of rounds are VL rounds. At the company level, $28.7 \%$ of the sample companies obtain at least one VL round. A descriptive study on European VL by the British Private Equity and Venture Capital Association (BVCA (2010)) suggests that VL started to evolve much later in Europe than in the United States, namely, at the end of the 1990s. The same study shows that in 2007 VL amounted to more than $10 \%$ of VC investments in the United Kingdom and almost $6 \%$ in Europe as a whole.

The reasons entrepreneurial companies at the pre-revenue stage are poor candidates for debt financing are many. From the perspective of agency-cost theories, debt gives rise to the asset substitution problem (Jensen and Meckling (1976)). It may also lead to underinvestment (Stulz (1990)) and generate information costs for creditors (Harris and Raviv (1990)). These disadvantages are of particular importance to entrepreneurial companies, for which investment opportunities are risky and the likelihood of failure is high. Agency-cost theories suggest that these disadvantages are traded off against the benefits of debt. More specifically, debt mitigates agency problems that arise between shareholders and managers, such as perk consumption (Jensen and Meckling (1976)) or overinvestment (Jensen (1986)). In entrepreneurial companies, however, such problems as perk consumption and overinvestment do not play a crucial role. Usually, these companies are not subject to the agency costs of free cash flows because their managers hold large stakes and these companies do not have excess cash flows. On the contrary, young entrepreneurial companies lack the stable cash flows they need to service and repay their debt. They typically have few assets in place to provide collateral to foreclose in the event of default. The theoretical literature on capital structure has demonstrated that companies with low levels of cash flows from operations and many growth opportunities rely on equity rather than debt (for a review of the literature, see Harris and Raviv (1991)). Older works, which draw on peckingorder theory (Myers and Majluf (1984)), conclude that entrepreneurial companies should prefer debt, because information asymmetry is large, making equity too expensive. However, the more recent literature suggests that such companies face severe debt capacity-constraints (Lemmon and Zender (2010)), which limit their 
ability to borrow. Moreover, empirical evidence does not provide much support for the pecking-order theory.

The literature uses these arguments to explain equity-like contracts used in VC financing. During the 1990s and early 2000s, the dominant view in the theoretical literature on VC was that convertible preferred equity securities are the optimal form of VC finance (Bergemann and Hege (1998), Casamatta (2003), Schmidt (2003), and many others) because they combine the advantages of equity financing with those of debt financing. More specifically, convertible preferred equity securities enable VC investors to participate in company upside potential; at the same time, these investors benefit from a liquidation preference if the company underperforms. Early empirical findings based on U.S. data also concur with this view (Kaplan and Strömberg (2003)). However, during the 2000s, empirical research demonstrates that $\mathrm{VC}$ investors often use other types of securities and that convertible preferred equity securities are not the dominant form of VC financing in many countries, including Canada (Cumming (2005), (2006)), Germany (e.g., Hartmann-Wendels, Keienburg, and Sievers (2011)), and other European countries (e.g., Cumming (2008), Cumming and Johan (2008b)).

My article contributes to this literature by deriving a theoretical model that explains why and when VC-backed companies that are financed with equity or equity-like instruments in the early stage obtain debt financing from VL investors in the late stage. In that respect, it also expands on theoretical studies that examine the use of debt in young entrepreneurial companies with uncertain prospects and how these companies choose between VC and bank finance. Winton and Yerramilli (2008) find that $\mathrm{VC}$ is optimal when i) the expected liquidation value is low if the venture fails, but expected returns are high if the venture turns successful; ii) the company development strategy is highly uncertain; and iii) the success probability is low. De Bettignies and Brander (2007) model a setting in which both the VC investor and the entrepreneur provide effort and a two-sided moral hazard problem arises. They demonstrate that in this setting, when VC investors can provide a high level of management support, companies prefer VC over bank finance. I also relate VL to the likelihood of success, adding to the literature on the relation between security type and exits (e.g., Cumming and Johan (2008a)).

My model captures major patterns I observe in financing young entrepreneurial companies with uncertain prospects that previous studies have largely ignored. First, my model explicitly takes into account that entrepreneurial companies typically obtain financing in several stages (Sahlman (1990)). More specifically, I explain the decision of early-stage VC investors to turn to either a late-stage VC or a VL investor to finance company growth, rather than make a one-off company decision between debt or equity. Second, my model acknowledges that, instead of deciding exclusively between VL and VC, entrepreneurial companies that obtain VL typically obtain VC as well (Hardymon et al. (2005), Ibrahim (2010)). Third, in line with the evidence, in my model, the company is financed by a VC investor in the early stage, whereas a VL investor may join in the late stage. Studies on both U.S.-based companies (Hardymon et al. (2005), Ibrahim (2010)) and European companies (BVCA (2010)) suggest this pattern is typical. Fourth, I take into account that entrepreneurial companies that obtain VC financing benefit from close monitoring and advice, which VC investors 
offer in addition to the capital injection. ${ }^{1}$ For example, Hellmann and Puri (2002) demonstrate that $\mathrm{VC}$ investors play a significant role in the professionalization of entrepreneurial companies. Although VC investors usually take board seats in their portfolio companies and are actively involved in their management (Amornsiripanitch, Gompers, and Xuan (2016)), VL investors usually do not have board seats and are much less active (e.g., Gordan (2012)). ${ }^{2}$ Fifth, I acknowledge that $\mathrm{VC}$ investors acquire extensive control rights that allow them to determine or at least codetermine who will be the new investors in the next stage.

The results I derive from my model suggest that in the case of perfect information, that is, when the late-stage investor receives the same (perfect) information about the entrepreneurial company as the early-stage $\mathrm{VC}$ investor, the latter prefers another VC round to a VL round. The reason is that the late-stage VC also provides monitoring and advice that may increase the company value. In the case of asymmetric information, that is, when the early-stage VC investor has more precise information about the prospects of the portfolio company than the potential new investor, the early-stage VC investor may strictly prefer VL to VC. I derive the financing choice in the late stage from a signaling model with varying proportions of high-quality and low-quality companies in the population. Earlystage VC investors prefer to signal the high quality of their companies and ask for VL, particularly for value companies (i.e., companies that have a high liquidation value but modest opportunities for growth). These companies use VC (without signaling) only if the proportion of high-quality companies in the population is high. For growth companies (i.e., companies with a high upside and a low liquidation value), early-stage VC investors prefer VC to VL. Also, if the late-stage $\mathrm{VC}$ investor can add considerable value through monitoring and advice, $\mathrm{VC}$ will be preferred over VL. This model also implies that when companies face high uncertainty, early-stage VC investors are more likely to turn to a VC partner, rather than to a VL partner, in the late stage. In the empirical part of this article, I look for proxies that can capture the factors I introduce and examine how these proxies relate to the choice of financing in the late stage.

In addition to shedding light on the rationales behind the emerging VL industry, this article demonstrates that a viable VL industry may lead to an increase in the number of companies that obtain early-stage VC. VL can be seen as a valuable option for early-stage VC investors. This option increases the value of their investment. This, in turn, makes them ex ante more willing to finance companies that would not be financed if only VC financing were available in the late stage. When only VC financing is available in the late stage, early-stage VC investors may have to dilute their stakes too much in the late stage in some cases. This results ex ante in negative net expected revenue, in which case the VC investor prefers not to participate in the early stage. VL may help reduce these inefficiencies that arise due to information asymmetries when late-stage financing is needed.

This article is organized as follows: In Section II, I briefly describe how the VC industry operates. In Section III, I present my model setup, and in Section IV,

${ }^{1}$ This aspect is considered in the De Bettignies and Brander (2007) model.

${ }^{2}$ See also http://www.ventureblog.com/2004/04/venture-lending-101.html. 
I develop it for a perfect information setting. In Section V, I introduce the choice of financing as a possible signal in the case of asymmetric information setting. In Section VI, I describe my data and present descriptive statistics. Finally, I discuss my empirical results in Section VII and conclude in Section VIII.

\section{Features of VC Financing}

Despite its modest size, the VC industry has given rise to many successful enterprises, some of which have produced major innovations. Such enterprises include Google, Intel, Apple, Microsoft, Cisco, Facebook, Skype, Sun Microsystems, Federal Express, Genentech, and many others. VC investors provide capital to young, innovative entrepreneurial companies that tend to have risky return distributions and inexperienced management (e.g., Sahlman (1990)). These investments are often plagued by substantial information asymmetries and agency problems. For that reason, VC investors have developed several mechanisms to help them cope with these problems. In the following section, I summarize the features of VC financing and the mechanisms that are key to my theoretical model.

One important mechanism involves staging investments (Sahlman (1990)), that is, providing financing in rounds, on the condition that the financed company reaches specific milestones. Staging gives VC investors the option to revalue the project and stop it. The threat of liquidation induces entrepreneurs to work hard and mitigates moral hazard behavior on their part (e.g., Bergemann and Hege (1998)). Staging may also help reduce the risk of adverse selection, because entrepreneurs who are not convinced of the high quality of their projects will not accept it. Consequently, staging may be employed as a signal that distinguishes good entrepreneurs from bad (Barry (1994)).

Another mechanism is syndication. Several studies argue that syndication with new investors in later stages may help early-stage VC investors cope with information asymmetries and agency problems. For example, Fluck, Garrison, and Myers (2005) demonstrate that the early-stage VC investor commitment to syndicate at a later stage can alleviate the holdup problem the entrepreneur faces. Admati and Pfleiderer (1994) argue that VC investors may take a suboptimal continuation decision when projects are financed in stages. In their model, syndication with outside VC investors at a later stage may resolve this problem. Empirical evidence suggests that VC investors typically specialize in financing a particular stage in a company's development. Consequently, when a company proceeds to the next stage of its development, it searches for new investors. Schwienbacher (2013), who collects data on VC funds raised between 2005 and 2011 in the United States, reports that $46.8 \%$ of the funds have an early-stage focus, $44.4 \%$ have a late-stage focus, and only $8.8 \%$ are generalists.

An important feature that distinguishes VC investors from VL investors is that the former offer monitoring and advice. Monitoring can help resolve problems that arise from the divergence of incentives between founder-managers and investors; advice can compensate for the insufficient experience of the foundermanagers. The active monitoring and advisory role of VC investors is explored in many studies, which demonstrate that these activities indeed add value. Hellmann and Puri (2002), for example, find that VC investors play an important role in the 
professionalization of the companies they finance. Compared to solo investors, in syndicated investments $\mathrm{VC}$ investors may combine their unique and potentially complementary resources (e.g., Manigart, Meuleman, Wright, Landstroem, Bruining, Desbrieres, and Hommel (2006)) and further increase the value added (e.g., Brander, Amit, and Antweiler (2002)).

My model also takes into account that VC investors do not obtain regular ongoing payments, such as dividends, from their portfolio companies. They instead finance these companies for a limited period and harvest at the exit (e.g., Cumming (2008)).

\section{Model Setup}

Consider an entrepreneurial company that has raised VC financing in the early stage. In the next (late) stage, the company needs 1 unit of capital. At the end of the early stage, the company does not produce a positive cash flow, so the late-stage investment must be financed from external sources. I assume that both early-stage and late-stage financing are provided by two different investors. This could be because the early-stage VC investor does not have sufficient funds to fully finance the necessary late-stage investment or specializes in early-stage finance. For simplicity, I assume that the early-stage investor does not provide any funds in the late round. However, this assumption does not affect the main conclusions I draw from my model; all that matters is that the company needs to find a new investor at the late stage. Many potential capital providers are willing to finance companies in the late stage. I expect competition to drive their returns toward 0. For simplicity, I also assume that all investors are risk neutral, and I set the discount rate to 0 . If the company fails to obtain late-stage investment, it is liquidated at the end of the first period. The liquidation value is $l$. If the early-stage VC investor succeeds in finding another capital provider for the late stage, liquid markets exist that allow VC investors to sell the company for its true value at the end of that period. ${ }^{3}$

The new investor may be either a debt or an equity investor. For simplicity, I refer to any debt investor as a "VL investor" and to any equity investor as a (late-stage) "VC investor," although VC investors can also provide debt finance (Cumming (2005), Cumming and Johan (2008b)). These categories of investors differ with respect to the type of financing as well as the services they provide. Late-stage VC investors provide specific advice and monitoring services that may increase the value of a high-quality company, whereas VL investors do not provide such services. Thus, early-stage VC investors face a trade-off when they decide whether to turn to a $\mathrm{VC}$ or a VL investor to finance the late stage. If they turn to a VC investor, their equity stake dilutes, because the late-stage VC investor obtains an equity fraction $\alpha$ in the company, whereas the VL investor obtains a fixed interest payment $i$. However, as equity investors, early-stage VC investors may profit from the contributions of late-stage VC investors, because the latter's services may increase the company value.

\footnotetext{
${ }^{3}$ The results I draw from the model still hold if VC investors keep their investments in the company instead of exiting. In this case, they hold shares of a known value instead of selling them at this value.
} 
I assume that only two types of companies (high quality and low quality) and two states of nature (high and low) exist. The expected company value depends on the type of financing in the late stage (VC or VL), the type of company, and the state of nature. With the participation of the early-stage VC investor (and financing from a VL investor in the late stage), in the high state the company value equals $h$, whereas in the low state there is no increase in the company value, which remains the same as the early-stage liquidation value $l(l<h)$. This applies to both company types. I assume that the liquidation value does not cover the late-stage investment $(l<1)$. The value of a high-quality company can be levered with the monitoring and advice services the late-stage VC investor provides. However, only high-quality companies in the high state can benefit from these services. When such companies obtain financing from a late-stage VC investor, their value increases to $k h(k>1)$. When there is no support from a VC investor, the company type does not affect the company value in either state, but does affect the likelihood of the high state of nature, which is higher for high-quality companies than for low-quality companies. High-quality companies are more likely (with probability $p>0.5$ ) to reach a high state, whereas low-quality companies are more likely to reach a low state. However, even high-quality companies have a probability $1-p$ of reaching a low state (whereas low-quality companies have the same probability of reaching a high state). This indicates there is an idiosyncratic risk as the result of which the exact late-stage outcome is uncertain at the end of the first period. The parameter $p$ captures the level of certainty. At the end of the first period, market participants form their expectations about the value of a low-quality $(b)$ company at the end of the next period:

$$
\mathrm{E}\left(V_{b}\right)=p l+(1-p) h .
$$

The expected value of a high-quality $(g)$ company that a VL cofinances is:

$$
\mathrm{E}\left(V_{g \mathrm{VL}}\right)=p h+(1-p) l .
$$

If a late-stage $\mathrm{VC}$ investor cofinances the high-quality company instead, its expected value is:

$$
\mathrm{E}\left(V_{g \mathrm{VC}}\right)=p k h+(1-p) l .
$$

\section{The Benchmark Model: Perfect Information}

Under perfect information, everybody can observe a company's true quality at the end of the first period. In a more realistic setting, which I discuss in Section $\mathrm{V}$, the early-stage $\mathrm{VC}$ investor receives information about the company type, whereas external investors cannot observe the company's quality until the end of the next period.

In my model, I ignore the entrepreneur and let the early-stage VC investor make the decision. Alternatively, I could imagine a group of "initial owners" (consisting of an early-stage VC investor and an entrepreneur) that provides monetary investment and make a joint effort in the early stage but remain passive in the late stage, for which they jointly choose a new investor. Several studies demonstrate 
that entrepreneurial effort is particularly beneficial in the early stage but less so in the late stage, when entrepreneurs are often replaced by professional outside managers (e.g., Hellmann and Puri (2002)).

Let us assume that low-quality companies are not worth funding in the late stage because their net expected value $p l+(1-p) h-1$ is lower than the liquidation value $l$ at the end of the first period. Let us furthermore assume that high-quality companies are worth funding in the second period, that is, $p h+(1-p) l-1>l$.

Because of perfect competition among potential new investors, these investors are willing to finance the company if they expect their initial investment of 1 unit to be repaid. For low-quality companies, the net expected value at the end of the second period turns negative. Thus, early-stage VC investors are better off if they terminate the investment and obtain $l$ instead of turning to a latestage investor. I derive early-stage VC investor exact payoffs in each situation in Appendix A. Because $p k h+(1-p) l-1>p h+(1-p) l-1>l$, early-stage VC investors that finance high-quality companies choose not to terminate, and their preferred choice is VC. Late-stage VC investors obtain a fraction,

$$
\alpha_{\mathrm{SYM}}=\frac{1}{p k h+(1-p) l} .
$$

The potential disadvantage of sharing the upside when the companies obtain $\mathrm{VC}$ is thus irrelevant under perfect information, because the additional value that late-stage VC investors generate accrues to early-stage VC investors because of competition in the late-stage market. Because I do not want to introduce a further parameter in the model, I assume that late-stage VC investors' effort is costless $(c=0)$. However, if late-stage VC investors exert costly effort $(c>0)$, they must be compensated (and obtain at least $1+c$ to break even). As long as the effort cost $c$ is low enough $(p h(k-1)>c)$, the model outcome in the perfect information setting does not change. ${ }^{4}$ To sum up, low-quality companies are liquidated after the early stage, and high-quality companies obtain VC financing in the late stage. There is no VL.

\section{The Model: Asymmetric Information}

Under asymmetric information, incoming late-stage (VC or VL) investors are no longer able to observe the quality of a specific company. They only know the distribution of company types. The proportion of high-quality companies in the population is $\lambda(0<\lambda<1)$, which is the prior belief of potential late-stage investors about the probability of dealing with a high-quality company.

When the quality of the company is private information that only early-stage VC investors possess, the predictions I make in the previous section change substantially. In general, early-stage VC investors who own high-quality companies

\footnotetext{
${ }^{4}$ In the asymmetric information setting, costly effort leads to an incentive problem and decreases the relative attractiveness of $\mathrm{VC}$, especially that of $\mathrm{VC}$ pooling. For some parameter settings, the model outcome may change if I consider the cost of effort. As long as the cost of effort cost is low, the range of parameter combinations is relatively narrow. Because my model focuses on adverse selection, to avoid complicating my analysis I ignore moral hazard.
} 
suffer from the existence of low-quality companies. Because of this, separation through signaling may be a potentially beneficial strategy. As I show later, earlystage VC investors have to give up a larger fraction of equity or rely on VL when potential late-stage investors cannot identify the type of company with which they are dealing.

In the following section, I develop my model under asymmetric information and determine the optimal strategy for early-stage VC investors that finance highquality companies. In the process, I show how this strategy varies depending on a company's characteristics, late-stage VC investors' ability to add value, and market conditions.

My setting is a sequential Bayesian game. The early-stage VC investor makes the first move; that is, it either liquidates the company or announces how the company should be financed in the late stage. This announcement specifies whether the company should obtain VC or VL and the financing conditions (fraction $\alpha$ or interest rate $i$ ) at which late-stage investors can participate. Potential late-stage investors act after this announcement. Depending on the announced action, they update their beliefs about whether the company they are dealing with is of high quality on the basis of Bayes's rule. If it is possible to make predictions based on the early-stage VC investor's actions, late-stage investors' belief about the probability of facing a high-quality company changes compared to the prior belief $\lambda$.

\section{A. Venture Capital}

I start by modeling the situation in which VL does not exist so that the latestage investment can be financed only by a new VC investor. I relax this assumption in Sections V.B and V.C, in which I, respectively, consider VL financing and examine how the early-stage VC investor chooses between VC and VL. In Section IV, I establish the first-best behavior in a perfect information benchmark. When everybody can perfectly observe the company type, all high-quality companies obtain financing and all low-quality companies are liquidated. This outcome does not necessarily hold when information is asymmetric. The reason for this difference is that early-stage VC investors involved in low-quality companies benefit from mimicking high-quality companies.

If late-stage investors cannot distinguish whether the company is of high or low quality, early-stage VC investors that finance high-quality companies may decide to signal company quality by offering a higher fraction $\alpha_{\mathrm{SEP}}>\alpha_{\mathrm{SYM}}$ on the company. To prevent early-stage VC investors that back low-quality companies from mimicking them, early-stage VC investors that back high-quality companies must ensure that investors that back low-quality companies do not benefit from this behavior. When a low-quality company mimics a high-quality company, an early-stage VC investor in the low-quality company expects a value of $\left(1-\alpha_{\mathrm{SEP}}\right)(p l+(1-p) h)$. The investor compares this value to the company's value under truth telling, which equals $l$. Consequently, the incentive compatibility constraint of the low-quality type becomes $\left(1-\alpha_{\mathrm{SEP}}\right)(p l+(1-p) h) \leq l$, resulting in the minimum fraction that the high-quality type must give up to separate itself from the low-quality type:

$$
\alpha_{\mathrm{SEP}}=1-\frac{l}{p l+(1-p) h} .
$$


Furthermore, the incentives of early-stage VC investors that finance highquality companies also have to be taken into account. For a separating equilibrium to exist, these investors must benefit from separating their company from lowquality companies more than they would if i) they liquidated it or ii) their portfolio company were perceived as low quality. I assume that in the case of high-quality companies, the late-stage VC investor value added is large enough, that is,

$$
k>\frac{h(p-1)(l(p-1)+1)-l\left(l(p-1)^{2}+p\right)}{h(p-1) p(h-l)},
$$

to make liquidation an inferior choice to separating those companies from the low-quality companies.

Let us consider what happens if late-stage investors are not able to distinguish between high-quality and low-quality companies and if they believe that both types of companies are in the market. In that case, they expect a company value of $\lambda(p k h+(1-p) l)+(1-\lambda)(p l+(1-p) h)$ and require a fraction

$$
\alpha_{\mathrm{POOL}}=\frac{1}{\lambda(p k h+(1-p) l)+(1-\lambda)(p l+(1-p) h)} .
$$

VC investors that finance high-quality companies choose to separate the company from low-quality companies whenever $\alpha_{\mathrm{POOL}} \geq \alpha_{\mathrm{SEP}}$; otherwise, they choose to pool with the low-quality type. By the intuitive criterion, the separating equilibrium is uniquely selected (Cho and Kreps (1987)). Thus, if I consider only VC financing, the following proposition holds:

Proposition 1. Only VC Is Possible. If $\alpha_{\mathrm{POOL}} \geq \alpha_{\mathrm{SEP}}$, according to equations (5) and (6), a VC separating equilibrium exists. In this equilibrium, high-quality companies obtain late-stage VC financing, and the early-stage VC investor gives up a fraction $\alpha_{\mathrm{SEP}}$, whereas low-quality companies are liquidated, leaving the earlystage $\mathrm{VC}$ investor with the liquidation value of $l$.

If $\alpha_{\mathrm{POOL}}<\alpha_{\mathrm{SEP}}$, then both types obtain $\mathrm{VC}$ financing in the late stage. In this pooling equilibrium, the early-stage $\mathrm{VC}$ investor gives up a fraction $\alpha_{\mathrm{POOL}}$.

Without imposing further restrictions on the parameter values, no closedform solution exists. I solve the model numerically, for varying proportions of high-quality companies in the population $\lambda$, by using the base parametrization $(h=2.1, l=0.2, p=0.6, k=1.05)$ and by changing these parameters one at a time. I show the results in Figure 1. For higher $\lambda$, pooling becomes more attractive for investors in high-quality companies because the detrimental effects caused by the existence of low-quality companies are reduced. Pooling is more attractive for investors that finance growth rather than value companies (high values of $h$ ), for investors in companies with low liquidation values (low values of $l$ ), and when the late-stage VC investor is able to add large value (high values of $k$ ). 
FIGURE 1

Only Venture Capital Is Available

Figure 1 shows equilibrium outcomes for different proportions of high-quality companies in the population $\lambda$ when only venture capital (VC) is available. I use the base parametrization $(h=2.1, I=0.2, p=0.6, k=1.05)$ and change one parameter at a time.
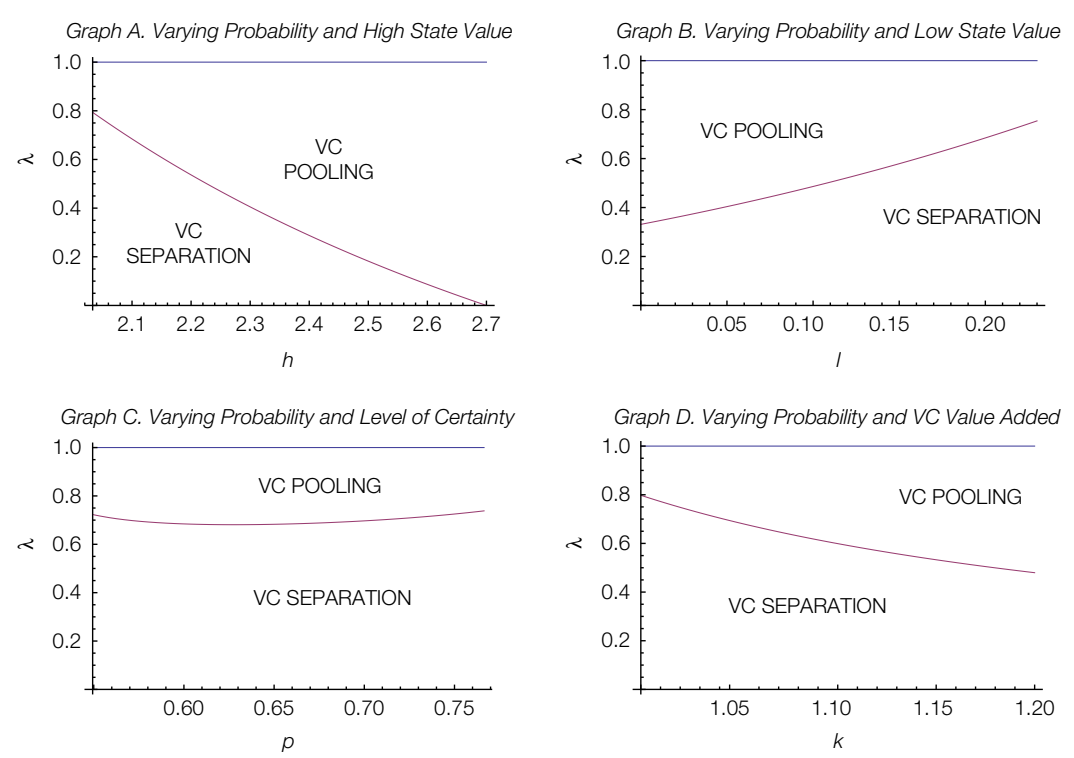

\section{B. Venture Lending}

I continue by modeling the situation in which the late-stage investment can come only from a VL investor. At the end of the second period, in the low state, the early-stage $\mathrm{VC}$ investor revenue is 0 , and the $\mathrm{VL}$ investor obtains $l<1$. In the high state, the early-stage $\mathrm{VC}$ investor gets $h-(1+i)$, and the VL investor obtains $(1+i)$.

If VL investors cannot determine whether a company is of high or low quality, early-stage VC investors that finance high-quality companies may decide to signal their portfolio companies' quality by offering an interest rate $i_{\mathrm{SEP}}$. To prevent $\mathrm{VC}$ investors that finance low-quality companies from mimicking, $\mathrm{VC}$ investors that finance high-quality companies must ensure that $\mathrm{VC}$ investors in lowquality companies do not benefit from following the high-quality type. When the low-quality type mimics the high-quality type, the early-stage investor expects a value of $p l+(1-p) h-(1+i)$ and compares this value to the value under truth telling, which is $l$. Consequently, the incentive compatibility constraint of the investor that finances the low-quality type becomes $p \times 0+(1-p)(h-(1+i)) \leq l$, resulting in the minimum interest rate that the high-quality company must pay to separate itself from the low-quality company:

$$
i_{\mathrm{SEP}}=h-1-\frac{l}{1-p}
$$


For a separating equilibrium to exist, VC investors that finance high-quality companies must benefit more from being distinguished from low-quality companies than they would if they were liquidated. I assume that high-quality companies in the high state are valuable enough $(h>l+l /(1-p)+(1-l) / p)$ to make liquidation an inferior choice to separating for their investors.

Moreover, VC investors that finance high-quality companies must prefer separating to being perceived as financing a low-quality company. Let us consider what happens if the latter occurs; VL investors are unable to distinguish between high-quality and low-quality companies and believe that both company types are in the market. In this situation, VL investors expect to receive $\lambda(p(1+i)+(1-p) l)+(1-\lambda)(p l+(1-p)(1+i))$ and require a fraction:

$$
i_{\mathrm{POOL}}=\frac{p-l p+\lambda-l \lambda-2 p \lambda+2 l p \lambda}{1-p-\lambda+2 p \lambda} .
$$

The early-stage VC investor that finances a high-quality company chooses to separate whenever $i_{\mathrm{POOL}} \geq i_{\mathrm{SEP}}$; otherwise, the investor pools with low-quality companies. By the intuitive criterion (Cho and Kreps (1987)), the separating equilibrium is uniquely selected. This leads to the following proposition:

Proposition 2. Only VL Is Possible. If $i_{\mathrm{POOL}} \geq i_{\mathrm{SEP}}$, according to equations (7) and (8), a VL separating equilibrium exists. In this equilibrium, high-quality companies obtain late-stage VL and the early-stage VC investor promises to pay an interest rate $i_{\mathrm{SEP}}$, whereas low-quality companies are liquidated, leaving the earlystage VC investor with the liquidation value of $l$.

If $i_{\mathrm{POOL}}<i_{\mathrm{SEP}}$, both types obtain VL in the late stage. In this pooling equilibrium, the early-stage $\mathrm{VC}$ investor promises to pay an interest rate $i_{\mathrm{POOL}}$.

The choice between VL pooling and separation depends on the constellation of parameters. I again modify the base parametrization $(h=2.1, l=0.2, p=0.6$, $k=1.05$ ) by varying one parameter at a time. The proportion of high-quality companies in the population is $\lambda$. I depict the results in Figure 2.

As in the case of $\mathrm{VC}$, for higher $\lambda$, pooling becomes more attractive for investors in high-quality companies. Also, pooling is more attractive for investors in growth rather than value companies (high values of $h$ ) and for investors that finance companies with low liquidation values (low values of $l$ ). Clearly, in a setting where in the late stage only VL is available, the late-stage VC investor's ability to add value is irrelevant.

\section{The Choice between VC and VL and Empirical Predictions}

Under symmetric information, VL is never the optimal method of financing, because the value-adding potential of the late-stage VC investor remains unused, and thus VL induces a dead-weight loss. However, if information becomes asymmetric, applying for VL might serve as a signal. As I show later, in some situations, even VL pooling may occur. Early-stage VC investors that finance highquality companies select among $\mathrm{VC}_{\mathrm{POOL}}, \mathrm{VC}_{\mathrm{SEP}}, \mathrm{VL}_{\mathrm{POOL}}$, and $\mathrm{VL}_{\mathrm{SEP}}$ and realize the following expected revenues (see Appendix B):

$$
\mathrm{RVC}_{g, \mathrm{POOL}}=\frac{h k p+l(-p)+l-1}{h((\lambda k+\lambda-1) p-\lambda+1)+l(-2 \lambda p+p+\lambda)},
$$


FIGURE 2

Only Venture Lending Is Available

Figure 2 shows equilibrium outcomes for different proportions of high-quality companies in the population $\lambda$ when only venture lending $(\mathrm{VL})$ is available. I use the base parametrization $(h=2.1, l=0.2, p=0.6, k=1.05)$ and change one parameter at a time. VC stands for venture capital.
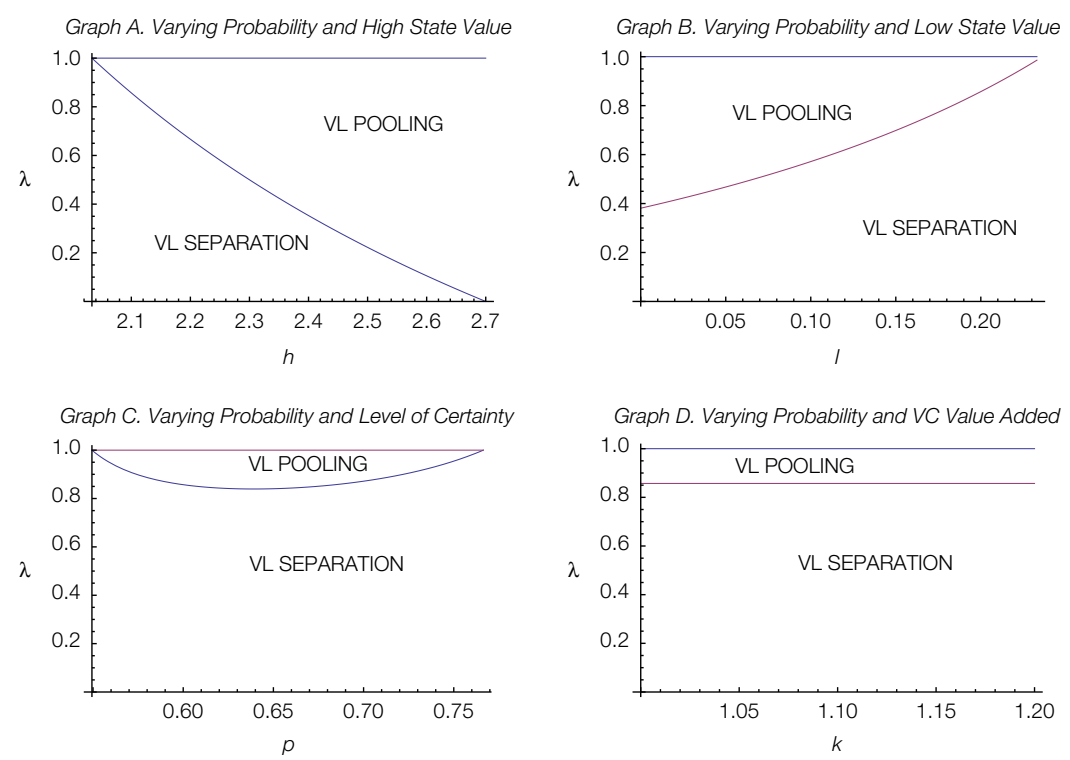

$$
\begin{gathered}
\mathrm{RVC}_{g, \mathrm{SEP}}=\frac{l(h k p+l(-p)+l)}{h(-p)+h+l p}, \\
\mathrm{RVL}_{g, \mathrm{POOL}}=\frac{p(h((2 \lambda-1) p-\lambda+1)+l(-2 \lambda p+p+\lambda)-1)}{(2 \lambda-1) p-\lambda+1}, \\
\mathrm{RVL}_{g, \mathrm{SEP}}=\frac{l p}{1-p} .
\end{gathered}
$$

High-quality companies are never liquidated, as $\mathrm{RVL}_{g, \mathrm{SEP}}$ generates a higher expected revenue for the early-stage $\mathrm{VC}$ investor than liquidation $(l p /(1-p)>l$ because $p>0.5)$. Under different parameter constellations, early-stage VC investors that finance high-quality companies make different decisions, which are detailed in Table 1. By the intuitive criterion, the separating equilibrium is uniquely selected (Cho and Kreps (1987)). Without imposing further restrictions on the parameter values, no closed-form solution exists. I once more solve the model numerically by using the base parametrization $(h=2.1, l=0.2, p=0.6, k=$ $1.05)$ and by varying one parameter at a time.

From Figure 3, I derive the following empirical predictions: If the proportion of high-quality companies in the current population $\lambda$ is sufficiently high, 
FIGURE 3

\section{Choice between VC and VL}

Figure 3 shows equilibrium outcomes for different proportions of high-quality companies in the population $\lambda$ when both venture capital (VC) and venture lending (VL) are available. I use the base parametrization $(h=2.1, l=0.2, p=0.6, k=$ 1.05) and change one parameter at a time.
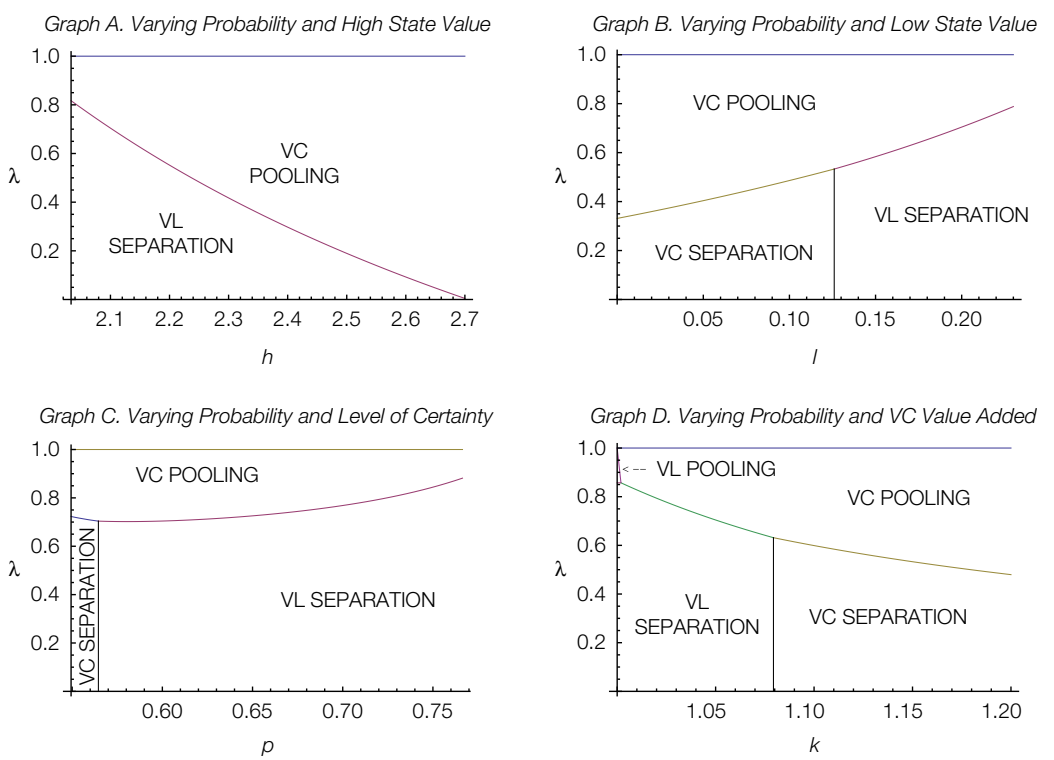

TABLE 1

Choice between VC and VL

Table 1 depicts the decisions that early-stage venture capital (VC) investors financing high-quality companies take under different parameter constellations. The respective formulas for the calculation of $\alpha_{\mathrm{POOL}}, \alpha_{\mathrm{SEP}}, i_{\mathrm{POOL}}, i_{\mathrm{SEP}}, \mathrm{RVC}_{g, \mathrm{POOL}}$, $\mathrm{RVC}_{g, \mathrm{SEP}}, \mathrm{RVL}_{g, \mathrm{POOL}}$, and $\mathrm{RV} \mathrm{L}_{g, \mathrm{SEP}}$ are listed in Section $\mathrm{V}$. VL stands for venture lending.

Condition

\begin{tabular}{|c|c|c|c|c|}
\hline Situation & 1 & 2 & 3 & Decision \\
\hline 1 & $\alpha_{\mathrm{POOL}}<\alpha_{\mathrm{SEP}}$ & $i_{\mathrm{POOL}}<i_{\mathrm{SEP}}$ & $\mathrm{RVC}_{g, \mathrm{POOL}}<\mathrm{RVL}_{g, \mathrm{POOL}}$ & $\mathrm{RVL}_{g, \mathrm{POOL}}$ \\
\hline 2 & $\alpha_{\mathrm{POOL}}<\alpha_{\mathrm{SEP}}$ & $i_{\mathrm{POOL}}<i_{\mathrm{SEP}}$ & $\mathrm{RVC}_{g, \mathrm{POOL}} \geq \mathrm{RVL}_{g, \mathrm{POOL}}$ & $\mathrm{RVC}_{g, \mathrm{POOL}}$ \\
\hline 3 & $\alpha_{\mathrm{POOL}} \geq \alpha_{\mathrm{SEP}}$ & $i_{\text {POOL }}<i_{\text {SEP }}$ & $\mathrm{RVC}_{g, \mathrm{SEP}}<\mathrm{RVL}_{g, \mathrm{POOL}}$ & $\mathrm{RVL}_{g, \mathrm{POOL}}$ \\
\hline 4 & $\alpha_{\mathrm{POOL}} \geq \alpha_{\mathrm{SEP}}$ & $i_{\mathrm{POOL}}<i_{\text {SEP }}$ & $\mathrm{RVC}_{g, \mathrm{SEP}} \geq \mathrm{RVL}_{g, \mathrm{POOL}}$ & $\mathrm{RVC}_{g, \mathrm{SEP}}$ \\
\hline 5 & $\alpha_{\mathrm{POOL}}<\alpha_{\mathrm{SEP}}$ & $i_{\text {POOL }} \geq i_{\text {SEP }}$ & $\mathrm{RVC}_{g, \mathrm{POOL}}<\mathrm{RVL}_{g, \mathrm{SEP}}$ & $\mathrm{RVL}_{g, \mathrm{SEP}}$ \\
\hline 6 & $\alpha_{\mathrm{POOL}}<\alpha_{\mathrm{SEP}}$ & $i_{P O O L} \geq i_{\text {SEP }}$ & $\mathrm{RVC}_{g, \mathrm{POOL}} \geq \mathrm{RVL}_{g, \mathrm{SEP}}$ & $\mathrm{RVC}_{g, \mathrm{POOL}}$ \\
\hline 7 & $\alpha_{\mathrm{POOL}} \geq \alpha_{\mathrm{SEP}}$ & $i_{\mathrm{POOL}} \geq i_{\mathrm{SEP}}$ & $\mathrm{RVC}_{g, \mathrm{SEP}}<\mathrm{RVL}_{g, \mathrm{SEP}}$ & $\mathrm{RVL}_{g, \mathrm{SEP}}$ \\
\hline 8 & $\alpha_{\mathrm{POOL}} \geq \alpha_{\mathrm{SEP}}$ & $i_{\mathrm{POOL}} \geq i_{\mathrm{SEP}}$ & $\mathrm{RVC}_{g, \mathrm{SEP}} \geq \mathrm{RVL}_{g, \mathrm{SEP}}$ & $\mathrm{RVC}_{g, \mathrm{SEP}}$ \\
\hline
\end{tabular}

companies of this type pool with low-quality companies in the late stage and use VC. If the proportion of high-quality companies is low, early-stage VC investors that finance high-quality companies tend to prefer VL in the late stage and signal the type of the company they back. Moreover, when high-quality companies can profit sufficiently from the value that late-stage $\mathrm{VC}$ investors can provide $k$, earlystage $\mathrm{VC}$ investors tend to ask a VC investor to join them in the late stage. Also, in periods of high volatility (low level of certainty $p$ ), early-stage $\mathrm{VC}$ investors turn to other VC investors rather than to a VL investor. Finally, early-stage VC investors that finance high-quality value companies (i.e., companies with a low 
upside potential $h$ and a high liquidation value $l$ ) prefer VL in the late stage and signal the type of companies they finance.

\section{Threshold Level for Early-Stage VC Financing}

As I show, under some parameter constellations, VL generates higher expected revenues for early-stage $\mathrm{VC}$ investors that finance a high-quality company than VC financing does. In this section, I examine whether more or fewer projects obtain early-stage financing when I extend the set of potential financing choices to include VL as an alternative to VC in the late stage.

Let us consider how an early-stage VC investor decides whether to invest an amount $I$ in a new company. This potential investor is informed about the parameter constellation $(h, l, p, k$, and $\lambda)$ but does not know whether the company is of high or low quality. Thus, the early-stage $\mathrm{VC}$ investor knows the revenuemaximizing solution (and the level of its revenue) in each case, that is, if the company turns out to be of high quality or of low quality.

The VC investor forms return expectations by weighting these values by $\lambda$ and $(1-\lambda)$ and invests in a company only if the required investment $I$ does not exceed the expected return. Let us denote as $I_{T}$ the early-stage investment threshold for which the VC investor just breaks even. Companies that require investments exceeding $I_{T}$ do not obtain early-stage VC financing. If I restrict late-stage financing to $\mathrm{VC}, I_{T}$ may decrease, in which case fewer companies obtain early-stage $\mathrm{VC}$ financing than if both VC and VL are available. However, $I_{T}$ may also increase, in which case more companies get early-stage VC financing than if both VC and VL are available. The latter applies when the preferred choice in the late stage is VL if both VL and VC are available, and VC pooling if VL is not available. The reason for this outcome is that early-stage VC investors that finance low-quality companies benefit from VC pooling, which generates a higher expected revenue than VL separation. If the size of this "benefit" weighted $(1-\lambda)$ exceeds the "loss" for investors that finance high-quality companies weighted $\lambda$, the threshold for project financing rises if both VC and VL are possible. In most situations, the existence of $\mathrm{VL}$ increases the number of positive-value projects and thus the amount of early-stage VC financing. As Figures 1 and 2 show, there are only a few parameter constellations under which the opposite is the case (specifically, I observe VL separation in Figure 2 and VC pooling in Figure 1). ${ }^{5}$

Table 2 illustrates this point with a numerical example based on my base parametrization. It shows the threshold levels $I_{T}$ for varying shares of high-quality companies in the population when both $\mathrm{VC}$ and $\mathrm{VL}$ are available (Panel A) and when only VC is available (Panel B). In most situations, the option of using VL in the late stage increases the threshold for the early-stage investment. ${ }^{6}$

${ }^{5}$ The threshold with VL separation is $\lambda l p /(1-p)+(1-\lambda) l$. With VC pooling it reaches $h((\lambda k+$ $\lambda-1) p-\lambda+1)+l(-2 \lambda p+p+\lambda)-1$.

${ }^{6}$ In this analysis, as in the previous sections, to keep the number of parameters tractable, I do not take into account that the VC investors' effort may be costly. If the effort of late-stage VC investors is costly, ceteris paribus, VL becomes more attractive in that stage. If the effort of early-stage $\mathrm{VC}$ investors is costly, the threshold level drops regardless of whether VL is an option. The reason is that in this case, early-stage VC investors require compensation not only for their monetary contribution but also for their efforts in the early stage. 
TABLE 2

Threshold Investment Levels for Early-Stage VC Financing

\begin{tabular}{|c|c|c|c|c|c|}
\hline & & & $\lambda$ & & \\
\hline & 0.1 & 0.3 & 0.5 & 0.7 & 0.9 \\
\hline \multicolumn{6}{|c|}{ Panel A. Both VC and VL Available } \\
\hline $\begin{array}{l}\text { Choice } \\
I_{T}\end{array}$ & $\begin{array}{c}V L_{\text {SEP }} \\
0.2100\end{array}$ & $\begin{array}{c}V L_{\text {SEP }} \\
0.2300\end{array}$ & $\begin{array}{c}V L_{\text {SEP }} \\
0.2500\end{array}$ & $\begin{array}{l}V L_{\text {SEP }} \\
0.2700\end{array}$ & $\begin{array}{l}\text { VC } C_{\text {Pool }} \\
0.3587\end{array}$ \\
\hline \multicolumn{6}{|c|}{ Panel B. Only VC Available (VL not available) } \\
\hline $\begin{array}{l}\text { Choice } \\
I_{T}\end{array}$ & $\begin{array}{l}V_{\text {SEP }} \\
0.2092\end{array}$ & $\begin{array}{l}V C_{\text {SEP }} \\
0.2277\end{array}$ & $\begin{array}{l}V C_{\text {SEP }} \\
0.2461\end{array}$ & $\begin{array}{l}V C_{\text {Pool }} \\
0.2701\end{array}$ & $\begin{array}{l}V_{\text {Pool }} \\
0.3587\end{array}$ \\
\hline
\end{tabular}

\section{Data and Descriptive Statistics}

My model yields several predictions, which I test empirically. To do this, I employ a sample of U.S. VC-backed start-ups founded between 1995 and 2008. I track financing rounds and exits of all my sample companies until the end of 2013. I combine data on deals with data on companies, VC firms, and VC funds as well as market from several sources: Dow Jones Venture Source, Standard \& Poor's (S\&P) Capital IQ, Bureau van Dijk Orbis, National Venture Capital Association (NVCA), Thomson ONE, and various Web sites and reports. Appendix C provides descriptions of all the variables I use and their sources.

\section{A. Data on VL and Exits}

My main data source is the Dow Jones Venture Source database, which provides information on the financing rounds and exits of VC-backed companies. To identify new financing rounds and exits, Venture Source relies on information from investors, which are supposed to update their data quarterly. In addition, Venture Source scans public disclosures, Web pages, news providers, and other sources. For my purposes, the major advantage of Venture Source compared to other commercially available VC databases, such as Thomson ONE, is that it includes rounds financed by VL investors, whereas other databases record only rounds in which VC investors participate. Moreover, the coverage of VC rounds in Venture Source is at least as good as, and recently even better than, their coverage in Thomson ONE (see Table 3).

From Venture Source, I extract information on the financing rounds between 1995 and 2013 of all VC-backed U.S. companies that were founded between 1995 and 2008. I choose to leave out companies founded after 2008 because I want to include all financing rounds as well as the exit event for each sample company. From the initially extracted sample, I remove companies for which I do not know the exact date of each financing round and companies with a management buy-in and public investments in a private company. The final sample consists of 50,623 financing rounds in 12,629 VC-backed companies.

Table 4 depicts the sample composition: 3,625 of the VC-backed companies obtain VL, which corresponds to $28.7 \%$ of all sample companies, and $15.9 \%$ of all rounds contain VL. VL is most prominent in energy and utilities and in healthcare. 
TABLE 3

\section{VC Deal Coverage in Dow Jones Venture Source and Thomson ONE}

Table 3 depicts the number of venture capital (VC) deals and their volumes (in US\$ millions) between 1995 and 2013 in the United States. The data are drawn from Dow Jones Venture Source and Thomson ONE.

$\underline{\text { Panel A. Dow Jones Venture Source }}$

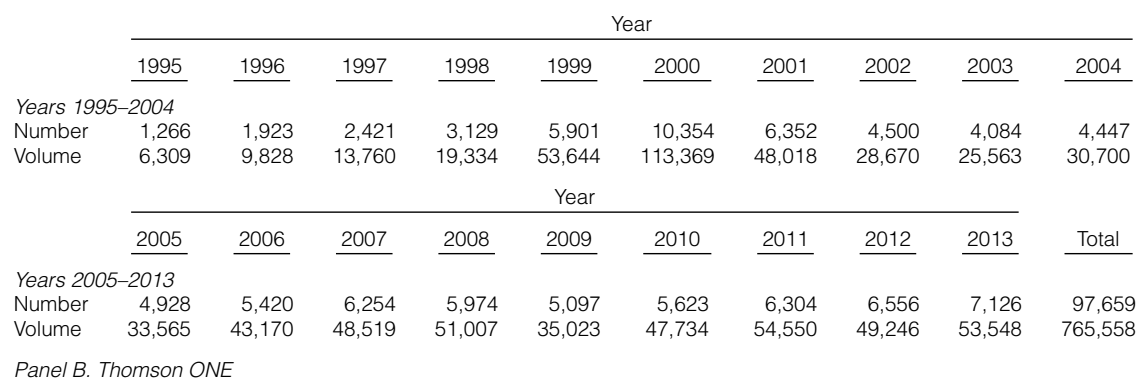

Panel B. Thomson ONE

\begin{tabular}{|c|c|c|c|c|c|c|c|c|c|c|}
\hline & \multicolumn{10}{|c|}{ Year } \\
\hline & 1995 & 1996 & 1997 & 1998 & 1999 & 2000 & 2001 & 2002 & 2003 & 2004 \\
\hline \multicolumn{11}{|c|}{ Years 1995-2004 } \\
\hline Number & 1,897 & 2,635 & 3,232 & 3,743 & 5,606 & 8,042 & 4,595 & 3,217 & 3,036 & 3,236 \\
\hline \multirow[t]{3}{*}{ Volume } & 8,017 & 11,285 & 15,073 & 21,539 & 54,911 & 105,012 & 40,938 & 22,192 & 19,679 & 22,858 \\
\hline & \multicolumn{10}{|c|}{ Year } \\
\hline & 2005 & 2006 & 2007 & 2008 & 2009 & 2010 & 2011 & 2012 & 2013 & Total \\
\hline \multicolumn{11}{|c|}{ Years 2005-2013 } \\
\hline Number & 3,300 & 3,890 & 4,230 & 4,199 & 3,173 & 3,667 & 4,039 & 3,964 & 4,238 & 73,939 \\
\hline Volume & 23,236 & 27,643 & 32,063 & 30,392 & 20,358 & 23,439 & 29,883 & 27,583 & 30,062 & 566,163 \\
\hline
\end{tabular}

\section{TABLE 4}

\section{Sample Composition by Industries}

Table 4 depicts the sample composition by industries. The data are from Dow Jones Venture Source.

Panel A. Rounds

\begin{tabular}{l} 
Industry (rounds) \\
\hline Business and financial services \\
Consumer goods \\
Consumer services \\
Energy and utilities \\
Healthcare \\
Industrial goods and materials \\
Information technology \\
Total number of rounds \\
Panel B. Companies \\
$\quad$ Industry (companies) \\
Business and financial services \\
Consumer goods \\
Consumer services \\
Energy and utilities \\
Healthcare \\
Industrial goods and materials \\
Information technology \\
Total number of companies
\end{tabular}

\begin{tabular}{c} 
Debt Rounds \\
\hline 1,159 \\
114 \\
627 \\
243 \\
2,586 \\
219 \\
3,095 \\
8,043
\end{tabular}

in $\%$
12.2
15.7
11.6
22.2
22.0
20.5
14.7
15.9

\begin{tabular}{c} 
Equity Rounds \\
\hline 8,336 \\
613 \\
4,769 \\
853 \\
9,160 \\
849 \\
18,000 \\
42,580
\end{tabular}

\begin{tabular}{|c|c|}
\hline in $\%$ & Total \\
\hline 87.8 & 9,495 \\
\hline 84.3 & 727 \\
\hline 88.4 & 5,396 \\
\hline 77.8 & 1,096 \\
\hline 78.0 & 11,746 \\
\hline 79.5 & 1,068 \\
\hline 85.3 & 21,095 \\
\hline 84.1 & 50,623 \\
\hline
\end{tabular}

Panel B. Companies

number of companies

\begin{tabular}{ccc} 
Debt and Equity & & in \% \\
\cline { 1 - 1 } 604 & & 22.7 \\
44 & 26.0 \\
347 & 20.5 \\
58 & 33.5 \\
888 & 40.1 \\
64 & 32.7 \\
1,620 & 29.3 \\
3,625 & 28.7
\end{tabular}

\begin{tabular}{c} 
Equity Only \\
\hline 2,051 \\
125 \\
1,345 \\
115 \\
1,327 \\
132 \\
3,909 \\
9,004
\end{tabular}

\begin{tabular}{|c|c|}
\hline in $\%$ & Total \\
\hline 77.3 & 2,655 \\
\hline 74.0 & 169 \\
\hline 79.5 & 1,692 \\
\hline 66.5 & 173 \\
\hline 59.9 & 2,215 \\
\hline 67.3 & 196 \\
\hline 70.7 & 5,529 \\
\hline 71.3 & 12,629 \\
\hline
\end{tabular}


I observe two upward jumps in VL: one after the burst of the dot-com bubble and one after the onset of the recent financial crisis. At the same time, I notice a drop in VC fundraising around these times (see Table 5). Table 6 provides a list of the 10 investors with the most VL deals in my sample. With the exception of OVP Venture Partners, a firm that also provides equity and equity-like financing, these investors specialize in VL.

Following much of the literature on VC performance (e.g., Hochberg, Ljungqvist, and Lu (2007), Cumming, Haslem, and Knill (2017)), I classify companies with an initial public offering (IPO) or a trade sale as successful. Although Venture Source provides data on exits, write-offs are underrepresented. The underrepresentation of "bad exits" is a common problem for researchers who deal with this and other similar databases that rely on information provided by market participants. To address this problem, I take the approach that previous studies establish and assume that companies that have not recorded any financing round for a "substantially long" period have been written off. More specifically, for each type of round, I calculate the 95th percentile of the time elapsed between this round and the next. If the last financing round recorded in Venture Source for a particular company is not an exit round and the time elapsed between this round and the end of the sample period exceeds the 95th percentile, I regard this company

TABLE 5

VL and VC Fundraising by Years

Table 5 depicts the proportion of venture lending (VL) rounds and venture capital (VC) fundraising volume (in US\$ billions) by years. The data are from Dow Jones Venture Source and National Venture Capital Association (2014).

Panel A. Years 1995-2004

\begin{tabular}{|c|c|c|c|c|c|c|c|c|c|c|}
\hline & \multicolumn{10}{|c|}{ Year } \\
\hline & 1995 & 1996 & 1997 & 1998 & 1999 & 2000 & 2001 & 2002 & 2003 & 2004 \\
\hline & $0.44 \%$ & $1.84 \%$ & $3.77 \%$ & $5.90 \%$ & $4.97 \%$ & $7.35 \%$ & $16.71 \%$ & $18.32 \%$ & $20.44 \%$ & $18.75 \%$ \\
\hline /C raised & 9.39 & 11.55 & 17.74 & 30.64 & 53.42 & 101.42 & 38.92 & 10.39 & 9.14 & 17.66 \\
\hline
\end{tabular}

Panel B. Years 2005-2013

\begin{tabular}{|c|c|c|c|c|c|c|c|c|c|c|}
\hline & \multicolumn{9}{|c|}{ Year } & \multirow[b]{2}{*}{ Total } \\
\hline & 2005 & 2006 & 2007 & 2008 & 2009 & 2010 & 2011 & 2012 & 2013 & \\
\hline $\begin{array}{l}\% \mathrm{VL} \\
\mathrm{VC} \text { raised }\end{array}$ & $\begin{array}{l}18.56 \% \\
30.07\end{array}$ & $\begin{array}{l}17.64 \% \\
31.11\end{array}$ & $\begin{array}{l}15.79 \% \\
29.40\end{array}$ & $\begin{array}{l}16.09 \% \\
25.05\end{array}$ & $\begin{array}{l}22.20 \% \\
16.12\end{array}$ & $\begin{array}{l}24.46 \% \\
13.24\end{array}$ & $\begin{array}{l}23.13 \% \\
18.96\end{array}$ & $\begin{array}{l}24.14 \% \\
19.55\end{array}$ & $\begin{array}{l}27.21 \% \\
16.77\end{array}$ & $\begin{array}{l}15.89 \% \\
500.55\end{array}$ \\
\hline
\end{tabular}

TABLE 6

List of Investors with the Most VL Deals in the Sample

Table 6 lists the investors with the most venture lending $(\mathrm{VL})$ deals in the sample. The data are from Dow Jones Venture Source.

\begin{tabular}{|c|c|}
\hline Rank & Investor Name \\
\hline 1 & Oxford Finance LLC \\
\hline 2 & Silicon Valley Bank \\
\hline 3 & Comdisco Ventures (liquidated) \\
\hline 4 & Hercules Technology Growth Capital Inc. \\
\hline 5 & MMV Capital Partners \\
\hline 6 & Western Technology Investment LLC \\
\hline 7 & ORIX Ventures \\
\hline 8 & OVP Venture Partners \\
\hline 9 & Comerica Bank \\
\hline 10 & Horizon Technology Growth Capital Inc. \\
\hline
\end{tabular}


as written off. Related studies, such as that by Hall and Woodward (2010), also impute write-off if no financing round occurs within a specified period. After applying this approach, I find that $77 \%$ of all companies have been exited at the end of my sample period. The bankruptcy rate among these companies is $49 \%$, which is very close to the $50 \%$ rate that Hall and Woodward observe in their sample.

\section{B. Regressors of Interest and Control Variables}

From my model, I conclude that VL is the preferred option if the proportion of high-quality companies in the current population is low. As a proxy for the proportion of such companies in the current population, I employ the variable FRAC_G, which reflects the success rate in the next period. The intuition behind this proxy is the following: When in a given period there are more high-quality companies in the population, the success rate in the next period should be higher. Consequently, in the regressions I conduct to explain the likelihood that a company obtains VL in a particular round, I expect a negative sign.

I also predict that if a company cannot profit much from a new $\mathrm{VC}$ investor value added, it will use VL instead. I expect that a new VC investor value added will be more beneficial when the company is young and has not been financed by a reputable VC in the past (see Cumming (2005)). Thus, my first proxy for the potential benefits from VC investor support is the variable AGE, which reflects company age and for which I obtain the relevant data (foundation date and date of each financing round) from Venture Source. As companies grow older, the potential for benefiting from a VC investor value added decreases (e.g., Bottazzi, Da Rin, and Hellmann (2008)), so they are more likely to obtain VL. I therefore expect a positive sign. I also use the Lee-Pollock-Jin (2011) VC Reputation Index and employ the variable RANK, which reflects the rank of the highest ranking VC that participated in previous rounds ( 1 is the top rank). As RANK increases, that is, as the rank declines, the potential for a new VC investor value added increases as well. Consequently, I expect a negative sign.

Moreover, my model suggests that uncertainty should be negatively related to the use of VL, which is consistent with what Cumming (2005) finds. To capture uncertainty, I calculate beta for the industry in which the company operates (IND_BETA). For the calculation, I employ industry index returns over the 125 trading days preceding the financing round, which I obtain from S\&P Capital IQ. This variable should have a negative sign.

In addition, a high liquidation value should support VL. A company liquidation value is positively related to the ratio of property, plant, and equipment to total assets (e.g., Lemmon and Zender (2010)), the ratio of fixed assets to total assets (e.g., Rajan and Zingales (1995)), or the ratio of tangible assets to total assets (e.g., Brav (2009)). For a very small subset of my sample, I obtain these characteristics (PPE_TA, FA_TA, TANG_TA) from the Bureau van Dijk Orbis database. I use the Orbis online database, which covers 2005-2014, as well as historical Orbis databases. Unfortunately, for the greatest part of my sample, there are no company-specific data available. I expect these variables to have a positive sign.

My model further implies that VL is associated with low-upside companies. I expect that the upside is reflected in how the VC investor exits. I conjecture that companies with a low upside are less likely to have a successful exit than 
companies with a higher upside. For that reason, I conduct separate regressions to investigate the exit outcomes of the companies in my sample, predicting a negative relation between VL and a successful exit.

To control for key conditions in the VC industry, I include the variable VC, which captures annual VC fundraising activity in the United States (National Venture Capital Association (2010)). I also add dummies for U.S. states with a high degree of VC or VL activity (namely, California, Massachusetts, New York, Texas, and Pennsylvania); all other states represent the omitted category. Moreover, I include VC firm and fund characteristics that prior works find to be relevant to the choice of security type and exit outcome (e.g., Cumming and Dai (2010), (2011)). These characteristics include VC firm age (VC_AGE), dummies for VC firm type (INDEP, CVC, GOVT), distance to the portfolio company (DIST), and VC fund size (LFS) and its square $\left(\mathrm{LFS}^{2}\right)$. The respective data come from Venture Source, Thomson ONE, and other sources. Unfortunately, data on VC fund size are available for only a small number of observations.

\section{Empirical Results}

\section{A. Determinants of VL}

Table 7 depicts the results I obtain from logit regressions on the round level. The binary dependent variable equals 1 if a company obtains VL in a particular round, and 0 otherwise. As regressors, I employ the variables described in Section VI.B as well as industry, time, and company fixed effects. The first three regressions include market and company characteristics (except financial characteristics) as well as VC investor rank. Note that as I add additional variables in subsequent regressions, the number of observations drops. Models 4-6 include VC firm controls. In models 7-9, I add VC fund controls. Finally, in models 10-12, I use company financial characteristics.

The results indicate that if the proportion of high-quality companies in the population is low, the likelihood that a company obtains VL instead of VC increases. FRAC_G has a negative sign and is highly statistically significant. The economic effect is small: In the first regression, a 1-standard-deviation decrease in FRAC_G raises the likelihood that a company obtains VL by 1.3 percentage points. The significance disappears when I include company fixed effects.

In line with the model prediction, the results suggest that companies that cannot profit much from the potential new VC investor value added use VL. Specifically, I find that AGE is positively related to the likelihood that a company obtains VL, which indicates that older companies are more likely to obtain VL. The economic effect is relatively large: A 1-standard-deviation increase in $\ln (\mathrm{AGE})$ is associated with a 5.1-percentage-point-higher likelihood that a company obtains VL. Again, however, this significance disappears when I include company fixed effects. I furthermore find that RANK has a negative sign and is highly significant, which supports the view that the company is more likely to obtain VL when a high-ranking VC (i.e., when the value of RANK is low) has provided financing to the company in the past. In model 1 of Table 7, the likelihood of a company obtaining VL decreases by 2.4 percentage points with a 1-standard-deviation increase in RANK. In models 7 and 8 , RANK is insignificant. However, in these 
models, the coefficient on VC_AGE, which some studies use as a proxy for VC reputation (e.g., Cumming and Dai (2010)), is significant. The sign is positive, which suggests that when reputable lead VC investors have been involved in earlier financing rounds, the likelihood that this company obtains VL increases. In model 7, a 1-standard-deviation increase in $\ln$ (VC_AGE) is associated with a 2.2percentage-point-higher likelihood that a company obtains VL.

Companies are less likely to use VL when uncertainty is high, which is reflected in the negative coefficient on IND_BETA. A 1-standard-deviation increase in IND_BETA is related to a 1.1-percentage-point-lower likelihood of VL. The

TABLE 7

Determinants of Venture Debt

Table 7 depicts the results of logit regressions for which I use a binary dependent variable that reflects whether the company obtains venture lending $(\mathrm{VL})$ in the particular round. Appendix $\mathrm{C}$ provides variable definitions. The $p$-values are reported in parentheses, and standard errors are clustered by time and industry. ${ }^{*}{ }^{* *}$, and ${ }^{* * *}$ indicate significance at the $10 \%, 5 \%$, and $1 \%$ levels, respectively.

\begin{tabular}{|c|c|c|c|c|c|c|}
\hline \multirow[b]{2}{*}{ Variables } & \multicolumn{6}{|c|}{ Model } \\
\hline & 1 & 2 & 3 & 4 & 5 & 6 \\
\hline \multicolumn{7}{|c|}{ Panel A. Market Characteristics (models 1-6) } \\
\hline IND_BETA & $\begin{array}{c}-8.8773^{\star \star} \\
(0.0241)\end{array}$ & $\begin{array}{r}-7.2695^{\star} \\
(0.0682)\end{array}$ & $\begin{array}{c}3.6789 \\
(0.4401)\end{array}$ & $\begin{array}{r}-7.5767^{*} \\
(0.0584)\end{array}$ & $\begin{array}{r}-6.9580^{*} \\
(0.0870)\end{array}$ & $\begin{array}{c}-1.4365 \\
(0.8100)\end{array}$ \\
\hline FRAC_G & $\begin{array}{c}-0.3861^{\star \star} \\
(0.0254)\end{array}$ & $\begin{array}{c}-0.3849^{\star \star} \\
(0.0216)\end{array}$ & $\begin{array}{c}-1.0943^{\star * *} \\
(0.0003)\end{array}$ & $\begin{array}{c}-0.5021^{* *} \\
(0.0229)\end{array}$ & $\begin{array}{c}-0.4940^{\star *} \\
(0.0247)\end{array}$ & $\begin{array}{c}-1.2260^{\star \star} \\
(0.0019)\end{array}$ \\
\hline $\ln (\mathrm{VC})$ & $\begin{array}{c}-0.2653^{\star \star \star} \\
(0.0000)\end{array}$ & $\begin{array}{c}-0.2577^{\star \star \star} \\
(0.0000)\end{array}$ & $\begin{array}{c}-0.2362^{\star * *} \\
(0.0031)\end{array}$ & $\begin{array}{c}-0.2136^{* * *} \\
(0.0004)\end{array}$ & $\begin{array}{c}-0.2099^{* * *} \\
(0.0002)\end{array}$ & $\begin{array}{c}-0.2766^{\star \star} \\
(0.0067)\end{array}$ \\
\hline
\end{tabular}

Panel B. Company Characteristics (models 1-6)

\begin{tabular}{|c|c|c|c|c|c|c|}
\hline $\ln (A G E)$ & $\begin{array}{l}0.4050^{\star \star \star} \\
(0.0000)\end{array}$ & $\begin{array}{l}0.4002^{\star \star \star} \\
(0.0000)\end{array}$ & $\begin{array}{l}0.4770^{\star \star \star} \\
(0.0000)\end{array}$ & $\begin{array}{l}0.3633^{\star * \star} \\
(0.0000)\end{array}$ & $\begin{array}{l}0.3625^{\star \star \star} \\
(0.0000)\end{array}$ & $\begin{array}{l}0.4136^{\star \star \star} \\
(0.0000)\end{array}$ \\
\hline CALIF & $\begin{array}{l}-0.3615^{\star \star \star} \\
(0.0000)\end{array}$ & $\begin{array}{l}-0.3519^{\star \star \star} \\
(0.0000)\end{array}$ & $\begin{array}{l}-0.3332^{\star * *} \\
(0.0003)\end{array}$ & $\begin{array}{l}-0.3944^{* * *} \\
(0.0000)\end{array}$ & $\begin{array}{l}-0.3888^{* \star *} \\
(0.0000)\end{array}$ & $\begin{array}{l}-0.3197^{\star \star \star *} \\
(0.0069)\end{array}$ \\
\hline MAS & $\begin{array}{l}-0.1173^{\star \star} \\
(0.0125)\end{array}$ & $\begin{array}{l}-0.1140^{\star \star} \\
(0.0150)\end{array}$ & $\begin{array}{c}-0.2613^{* *} \\
(0.0206)\end{array}$ & $\begin{array}{c}-0.0938 \\
(0.1459)\end{array}$ & $\begin{array}{c}-0.0927 \\
(0.1483)\end{array}$ & $\begin{array}{r}-0.0935 \\
(0.5111)\end{array}$ \\
\hline NY & $\begin{array}{l}-0.4623^{\star \star \star} \\
(0.0000)\end{array}$ & $\begin{array}{l}-0.4582^{\star \star \star} \\
(0.0000)\end{array}$ & $\begin{array}{l}-0.6970^{\star * *} \\
(0.0004)\end{array}$ & $\begin{array}{l}-0.5900^{* * *} \\
(0.0000)\end{array}$ & $\begin{array}{l}-0.5880^{\star \star \star *} \\
(0.0000)\end{array}$ & $\begin{array}{l}-0.5865^{\star \star} \\
(0.0153)\end{array}$ \\
\hline TEX & $\begin{array}{l}-0.1646^{\star \star \star} \\
(0.0064)\end{array}$ & $\begin{array}{l}-0.1494^{\star \star} \\
(0.0147)\end{array}$ & $\begin{array}{c}0.0124 \\
(0.9417)\end{array}$ & $\begin{array}{c}-0.2736^{\star * *} \\
(0.0021)\end{array}$ & $\begin{array}{l}-0.2587^{\star \star \star} \\
(0.0044)\end{array}$ & $\begin{array}{c}-0.0680 \\
(0.7554)\end{array}$ \\
\hline PEN & $\begin{array}{l}0.1330^{\star \star} \\
(0.0323)\end{array}$ & $\begin{array}{l}0.1272^{\star \star} \\
(0.0373)\end{array}$ & $\begin{array}{c}-0.1796 \\
(0.4097)\end{array}$ & $\begin{array}{r}-0.0643 \\
(0.4989)\end{array}$ & $\begin{array}{c}-0.0728 \\
(0.4323)\end{array}$ & $\begin{array}{c}-0.2902 \\
(0.2848)\end{array}$ \\
\hline \multicolumn{7}{|c|}{ Panel C. VC Firm Characteristics (models 1-6) } \\
\hline RANK & $\begin{array}{l}-0.0003^{\star * \star} \\
(0.0000)\end{array}$ & $\begin{array}{l}-0.0003^{\star \star \star} \\
(0.0000)\end{array}$ & $\begin{array}{c}-0.0012^{\star * \star} \\
(0.0000)\end{array}$ & $\begin{array}{l}-0.0001^{* * *} \\
(0.0090)\end{array}$ & $\begin{array}{l}-0.0001^{\star \star \star} \\
(0.0100)\end{array}$ & $\begin{array}{l}-0.0009^{\star * *} \\
(0.0000)\end{array}$ \\
\hline $\ln \left(\mathrm{VC} \_A G E\right)$ & & & & $\begin{array}{c}0.0132 \\
(0.6471)\end{array}$ & $\begin{array}{c}0.0116 \\
(0.6877)\end{array}$ & $\begin{array}{c}-0.0911 \\
(0.1803)\end{array}$ \\
\hline INDEP & & & & $\begin{array}{c}0.0669 \\
(0.3836)\end{array}$ & $\begin{array}{c}0.0601 \\
(0.4347)\end{array}$ & $\begin{array}{c}0.0947 \\
(0.6694)\end{array}$ \\
\hline CVC & & & & $\begin{array}{l}-0.2821^{* *} \\
(0.0317)\end{array}$ & $\begin{array}{c}-0.2875^{\star \star} \\
(0.0273)\end{array}$ & $\begin{array}{r}-0.6395^{\star} \\
(0.0754)\end{array}$ \\
\hline GOVT & & & & $\begin{array}{l}0.5327^{\star \star \star} \\
(0.0003)\end{array}$ & $\begin{array}{l}0.5363^{\text {} \star \star \star ~} \\
(0.0002)\end{array}$ & $\begin{array}{r}0.6443^{*} \\
(0.0871)\end{array}$ \\
\hline DIST & & & & $\begin{array}{c}0.0000 \\
(0.9793)\end{array}$ & $\begin{array}{c}-0.0000 \\
(0.9729)\end{array}$ & $\begin{array}{r}-0.0000 \\
(0.6941)\end{array}$ \\
\hline $\begin{array}{l}\text { Industry fixed effects } \\
\text { Time fixed effects } \\
\text { Company fixed effects }\end{array}$ & $\begin{array}{l}\text { No } \\
\text { No } \\
\text { No }\end{array}$ & $\begin{array}{l}\text { Yes } \\
\text { No } \\
\text { No }\end{array}$ & $\begin{array}{l}\text { Yes } \\
\text { Yes } \\
\text { Yes }\end{array}$ & $\begin{array}{l}\text { No } \\
\text { No } \\
\text { No }\end{array}$ & $\begin{array}{l}\text { Yes } \\
\text { No } \\
\text { No }\end{array}$ & $\begin{array}{l}\text { Yes } \\
\text { Yes } \\
\text { Yes }\end{array}$ \\
\hline $\begin{array}{l}N \\
\chi^{2}\end{array}$ & $\begin{array}{c}34,439 \\
465.5665\end{array}$ & $\begin{array}{c}34,439 \\
507.0619\end{array}$ & $\begin{array}{c}8,856 \\
384.0210\end{array}$ & $\begin{array}{c}16,324 \\
282.7432\end{array}$ & $\begin{array}{c}16,324 \\
314.5058\end{array}$ & $\begin{array}{c}4,794 \\
137.1711\end{array}$ \\
\hline
\end{tabular}


coefficient on IND_BETA, however, loses its significance when I include company fixed effects. Furthermore, the effect becomes weaker when I add VC fund characteristics. 
All three variables used as proxies for liquidation value in models 10-12 are highly statistically significant and positive, which suggests that the likelihood of a company obtaining VL increases with higher liquidation value. A 1-standarddeviation increase in PPE_TA, FA_TA, and TANG_TA is related to a 4.4-, 6.2-, and 4.6-percentage-point-higher likelihood of VL, respectively. However, including these company-specific variables substantially reduces the size of my sample, as most of the companies are not represented in Orbis. All in all, the results in Table 7 support my model predictions.

\section{B. VL and Success}

To investigate the relation between VL and success, I apply Cox (1972) models and multinomial logit models.

Table 8 depicts the results I obtain from cross-sectional Cox (1972) models at the company level. These models take into account the right-censoring problem that arises because $23 \%$ of the sample companies have not been exited at the end of the sample period. The first two columns present the results of 1-event Cox proportional hazard models that regress the dependent variable time to successful exit (see, e.g., Nahata, Hazarika, and Tandon (2014)) on VL and other regressors. The dummy variable VL indicates whether the company has obtained VL in the past. As control variables, I include the characteristics of market, company, and VC firm that I describe in Section VI.B as well as industry and time fixed effects. In model 2, I add VC fund characteristics. The findings confirm the prediction that VL is associated with a low-quality exit. Companies that obtain VL have a $35 \%$ lower hazard rate compared to companies that are financed only by VC.

Besides distinguishing between success and failure, I conduct a more finegrained analysis to distinguish between different types of exits. For that purpose, I use a Cox model with competing risks (Fine and Gray (1999)). I focus on time to IPO (models 3 and 5 of Table 8 without and with VC fund characteristics, respectively) and time to private exit (models 4 and 6). According to Cumming and Johan (2010), private exits include acquisitions, buybacks, and secondary sales. I do not include time to write-off as a third category, as Cumming and Johan (2010) do, because I do not have a precise event date for a large number of the write-offs in my sample. In all four regressions, the coefficient on VL is significant and negative. The results again support the conclusion that VL is associated with a low-quality exit.

Following Cumming (2008), I estimate a multinomial logit regression with four categories of exits (IPOs, trade sales, secondary sales, write-offs) and nonexits as a reference category. The buybacks in my sample are too few to justify the addition of a separate category. Compared to estimating four separate logit models, using multinomial logit allows me to make a simultaneous estimation of the four binary logit models. It therefore leads to similar, but more efficient, parameter estimates.

Table 9 presents the marginal effects I obtain from using the cross-sectional multinomial logit model on the company level across the four exit categories. VL is associated with a lower probability of an IPO, trade sale, and secondary sale. VL decreases the probability of an IPO by 1.7 percentage points and the probability of a trade sale by 5.8 percentage points. The difference, however, is 
TABLE 8

Venture Debt and Success: Cox Models

Table 8 depicts the coefficients obtained from the Cox (1972) proportional hazard models (models 1 and 2), where I use the dependent variable time to successful exit. It also shows the coefficients derived from the Cox model with competing risks (Fine and Gray (1999)), where I use time to initial public offering (IPO) precluding private exit (models 3 and 5) and time to private exit precluding IPO (models 4 and 6 ). Appendix $C$ provides the variable definitions. The $p$-values are reported in parentheses and standard errors are clustered by time and industry. ${ }^{*},{ }^{* *}$, and ${ }^{* * *}$ indicate significance at the $10 \%, 5 \%$, and $1 \%$ levels, respectively. VC stands for venture capital.

\begin{tabular}{|c|c|c|c|c|c|c|}
\hline \multirow[b]{4}{*}{ Variables } & \multicolumn{6}{|c|}{ Dependent Variables } \\
\hline & $\begin{array}{c}\text { Time to } \\
\text { Exit }\end{array}$ & $\begin{array}{c}\text { Time to } \\
\text { Exit }\end{array}$ & $\begin{array}{l}\text { Time to } \\
\text { IPO }\end{array}$ & $\begin{array}{c}\text { Time to } \\
\text { Private Exit }\end{array}$ & $\begin{array}{l}\text { Time to } \\
\text { IPO }\end{array}$ & $\begin{array}{c}\text { Time to } \\
\text { Private Exit }\end{array}$ \\
\hline & \multicolumn{6}{|c|}{ Model } \\
\hline & 1 & 2 & 3 & 4 & 5 & 6 \\
\hline \multicolumn{7}{|c|}{ Panel A. Market Characteristics } \\
\hline IND_BETA & $\begin{array}{l}0.0246^{\star \star \star} \\
(0.0047)\end{array}$ & $\begin{array}{l}0.0273^{* * *} \\
(0.0030)\end{array}$ & $\begin{array}{c}-0.0687^{\star \star \star} \\
(0.0000)\end{array}$ & $\begin{array}{l}0.0236^{\text {** }} \\
(0.0045)\end{array}$ & $\begin{array}{c}-0.0311 \\
(0.2387)\end{array}$ & $\begin{array}{l}0.0229^{\star \star} \\
(0.0107)\end{array}$ \\
\hline FRAC_G & $\begin{array}{c}-0.2490 \\
(0.3101)\end{array}$ & $\begin{array}{r}-0.5158^{*} \\
(0.0784)\end{array}$ & $\begin{array}{c}0.4267 \\
(0.1914)\end{array}$ & $\begin{array}{r}-0.4863^{*} \\
(0.0648)\end{array}$ & $\begin{array}{c}0.3077 \\
(0.6340)\end{array}$ & $\begin{array}{c}-0.6309^{\star \star} \\
(0.0463)\end{array}$ \\
\hline $\ln (\mathrm{VC})$ & $\begin{array}{c}-0.4615^{\star \star \star} \\
(0.0032)\end{array}$ & $\begin{array}{c}-0.4303^{\star *} \\
(0.0116)\end{array}$ & $\begin{array}{c}-0.0189 \\
(0.9060)\end{array}$ & $\begin{array}{c}-0.4946^{\star \star \star} \\
(0.0034)\end{array}$ & $\begin{array}{c}-0.0237 \\
(0.9458)\end{array}$ & $\begin{array}{c}-0.4501^{\star \star \star} \\
(0.0081)\end{array}$ \\
\hline \multicolumn{7}{|c|}{ Panel B. Company Characteristics } \\
\hline $\mathrm{VL}$ & $\begin{array}{c}-0.4362^{\star \star \star} \\
(0.0000)\end{array}$ & $\begin{array}{c}-0.3259^{* * *} \\
(0.0000)\end{array}$ & $\begin{array}{c}-0.3945^{\star \star \star} \\
(0.0015)\end{array}$ & $\begin{array}{c}-0.3160^{\star \star \star} \\
(0.0000)\end{array}$ & $\begin{array}{c}-0.7973^{\star \star *} \\
(0.0026)\end{array}$ & $\begin{array}{r}-0.1398^{*} \\
(0.0559)\end{array}$ \\
\hline NUM_OF_INV & $\begin{array}{c}-0.1184^{\star \star \star} \\
(0.0000)\end{array}$ & $\begin{array}{c}-0.1468^{\star * *} \\
(0.0000)\end{array}$ & $\begin{array}{l}0.2052^{\star \star \star} \\
(0.0000)\end{array}$ & $\begin{array}{c}-0.1508^{\star \star \star} \\
(0.0000)\end{array}$ & $\begin{array}{l}0.2014^{* * *} \\
(0.0000)\end{array}$ & $\begin{array}{c}-0.1615^{\star \star \star} \\
(0.0000)\end{array}$ \\
\hline \multicolumn{7}{|c|}{ Panel C. VC Firm Characteristics } \\
\hline RANK & $\begin{array}{c}-0.0001^{\star \star \star} \\
(0.0008)\end{array}$ & $\begin{array}{c}-0.0001 \\
(0.1849)\end{array}$ & $\begin{array}{c}-0.0001 \\
(0.4316)\end{array}$ & $\begin{array}{c}-0.0001^{\star \star \star} \\
(0.0018)\end{array}$ & $\begin{array}{c}0.0003 \\
(0.3167)\end{array}$ & $\begin{array}{c}-0.0002 \\
(0.1131)\end{array}$ \\
\hline In(VC_AGE) & $\begin{array}{c}-0.2340^{\star \star \star} \\
(0.0000)\end{array}$ & $\begin{array}{c}-0.2693^{\text {*** }} \\
(0.0000)\end{array}$ & $\begin{array}{c}0.0264 \\
(0.7508)\end{array}$ & $\begin{array}{c}-0.1780^{\star \star \star} \\
(0.0000)\end{array}$ & $\begin{array}{c}0.1195 \\
(0.6969)\end{array}$ & $\begin{array}{c}-0.2272^{\star \star} \\
(0.0139)\end{array}$ \\
\hline INDEP & $\begin{array}{c}0.0152 \\
(0.8339)\end{array}$ & $\begin{array}{c}0.0502 \\
(0.7435)\end{array}$ & $\begin{array}{r}-0.3383^{\star} \\
(0.0959)\end{array}$ & $\begin{array}{c}0.1095 \\
(0.1296)\end{array}$ & $\begin{array}{c}-0.1473 \\
(0.8363)\end{array}$ & $\begin{array}{c}0.0359 \\
(0.8109)\end{array}$ \\
\hline CVC & $\begin{array}{c}-0.0390 \\
(0.7208)\end{array}$ & $\begin{array}{c}0.2449 \\
(0.1431)\end{array}$ & $\begin{array}{c}-0.0259 \\
(0.9256)\end{array}$ & $\begin{array}{c}-0.0332 \\
(0.7616)\end{array}$ & $\begin{array}{c}0.6848 \\
(0.4101)\end{array}$ & $\begin{array}{c}-0.0116 \\
(0.9605)\end{array}$ \\
\hline \multicolumn{7}{|c|}{ Panel D. VC Fund Characteristics } \\
\hline GOVT & $\begin{array}{r}-0.2693^{\star} \\
(0.0633)\end{array}$ & $\begin{array}{c}-0.0279 \\
(0.9194)\end{array}$ & $\begin{array}{c}-16.2583^{\star \star \star} \\
(0.0000)\end{array}$ & $\begin{array}{c}0.1018 \\
(0.4766)\end{array}$ & $\begin{array}{c}-13.1861^{\star * *} \\
(0.0000)\end{array}$ & $\begin{array}{c}0.0953 \\
(0.6959)\end{array}$ \\
\hline DIST & $\begin{array}{r}-0.0000^{*} \\
(0.0760)\end{array}$ & $\begin{array}{c}-0.0000 \\
(0.1687)\end{array}$ & $\begin{array}{l}0.0001^{\star * *} \\
(0.0033)\end{array}$ & $\begin{array}{c}-0.0000^{\star \star \star} \\
(0.0004)\end{array}$ & $\begin{array}{r}0.0002^{*} \\
(0.0517)\end{array}$ & $\begin{array}{r}-0.0000^{*} \\
(0.0938)\end{array}$ \\
\hline LFS & & $\begin{array}{c}0.1365 \\
(0.2257)\end{array}$ & & & $\begin{array}{l}3.0250^{\star \star \star} \\
(0.0000)\end{array}$ & $\begin{array}{r}-0.2359^{\star} \\
(0.0706)\end{array}$ \\
\hline LFS $^{2}$ & & $\begin{array}{c}-0.0106 \\
(0.2376)\end{array}$ & & & $\begin{array}{c}-0.8661^{\star \star *} \\
(0.0025)\end{array}$ & $\begin{array}{c}0.0226^{\star \star} \\
(0.0242)\end{array}$ \\
\hline $\begin{array}{l}\text { Industry fixed effects } \\
\text { Time fixed effects }\end{array}$ & $\begin{array}{l}\text { Yes } \\
\text { Yes }\end{array}$ & $\begin{array}{l}\text { Yes } \\
\text { Yes }\end{array}$ & $\begin{array}{l}\text { Yes } \\
\text { Yes }\end{array}$ & $\begin{array}{l}\text { Yes } \\
\text { Yes }\end{array}$ & $\begin{array}{l}\text { Yes } \\
\text { Yes }\end{array}$ & $\begin{array}{l}\text { Yes } \\
\text { Yes }\end{array}$ \\
\hline $\begin{array}{l}N \\
\chi^{2}\end{array}$ & $\begin{array}{c}6,268 \\
1,188.8154\end{array}$ & $\begin{array}{c}1,559 \\
764.7427\end{array}$ & $\begin{array}{c}6,268 \\
7,266.4986\end{array}$ & $\begin{array}{c}6,268 \\
576.7839\end{array}$ & $\begin{array}{c}1,559 \\
1,971.4651\end{array}$ & $\begin{array}{c}1,559 \\
424.9056\end{array}$ \\
\hline
\end{tabular}

not statistically significant. The probability of a secondary sale decreases by 1.4 percentage points.

My results suggest that VL is significantly and negatively related to a successful exit in general and to private exits, IPOs, trade sales, and secondary sales in particular. To check whether there are periods or industries where VL is associated with a positive outcome, I split the sample into four subsamples representing different periods and seven subsamples representing different industries. I rerun all regressions depicted in Tables 8 and 9 for each of these subsamples. In summary 
Venture Debt and Success: Multinomial Logit Models

Table 9 depicts the marginal effects obtained from multinomial logit models, where I use initial public offerings (IPOs), trade sales, secondary sales, and write-offs. Nonexited investments are the reference category. Appendix $C$ provides the variable definitions. The $p$-values are reported in parentheses and standard errors are clustered by time and industry. *, ${ }^{* *}$, and ${ }^{* * *}$ indicate significance at the $10 \%, 5 \%$, and $1 \%$ levels, respectively. VC stands for venture capital.

\begin{tabular}{|c|c|c|c|c|}
\hline \multirow[b]{2}{*}{ Variables } & \multicolumn{4}{|c|}{ Category } \\
\hline & $\mathrm{IPO}$ & Trade Sale & $\begin{array}{l}\text { Secondary } \\
\text { Sale }\end{array}$ & Write-Off \\
\hline \multicolumn{5}{|c|}{ Panel A. Market Characteristics } \\
\hline IND_BETA & $\begin{array}{l}-0.0032^{\star * *} \\
(0.0000)\end{array}$ & $\begin{array}{c}0.0070^{*} \\
(0.0550)\end{array}$ & $\begin{array}{c}-0.0000 \\
(0.9062)\end{array}$ & $\begin{array}{l}-0.0176^{\star \star \star} \\
(0.0000)\end{array}$ \\
\hline FRAC_G & $\begin{array}{c}0.0241 \\
(0.2631)\end{array}$ & $\begin{array}{l}-0.1372^{* \star \star} \\
(0.0069)\end{array}$ & $\begin{array}{l}-0.0106 \\
(0.1621)\end{array}$ & $\begin{array}{c}0.0286 \\
(0.5198)\end{array}$ \\
\hline $\ln (\mathrm{VC})$ & $\begin{array}{c}0.0106 \\
(0.1842)\end{array}$ & $\begin{array}{r}-0.0997^{\star} \\
(0.0722)\end{array}$ & $\begin{array}{c}-0.0023 \\
(0.6719)\end{array}$ & $\begin{array}{r}-0.1150^{*} \\
(0.0521)\end{array}$ \\
\hline \multicolumn{5}{|c|}{ Panel B. Company Characteristics } \\
\hline VL & $\begin{array}{l}-0.0170^{\star \star \star} \\
(0.0070)\end{array}$ & $\begin{array}{l}-0.0576^{\star \star \star} \\
(0.0000)\end{array}$ & $\begin{array}{l}-0.0135^{\star * *} \\
(0.0008)\end{array}$ & $\begin{array}{l}0.0137 \\
(0.1942)\end{array}$ \\
\hline NUM_OF_INV & $\begin{array}{l}0.0118^{\star \star \star} \\
(0.0000)\end{array}$ & $\begin{array}{c}-0.0038 \\
(0.1836)\end{array}$ & $\begin{array}{l}-0.0045^{\star \star \star} \\
(0.0002)\end{array}$ & $\begin{array}{l}0.0047^{\star \star} \\
(0.0185)\end{array}$ \\
\hline \multicolumn{5}{|c|}{ Panel C. VC Firm Characteristics } \\
\hline RANK & $\begin{array}{l}-0.0000 \\
(0.1317)\end{array}$ & $\begin{array}{c}-0.0001^{\star \star \star} \\
(0.0000)\end{array}$ & $\begin{array}{c}0.0000 \\
(0.4056)\end{array}$ & $\begin{array}{l}0.0001^{\star \star \star} \\
(0.0000)\end{array}$ \\
\hline In(VC_AGE) & $\begin{array}{c}0.0033 \\
(0.4584)\end{array}$ & 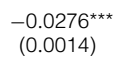 & $\begin{array}{c}0.0040 \\
(0.2844)\end{array}$ & $\begin{array}{l}0.0189^{\star \star \star} \\
(0.0066)\end{array}$ \\
\hline INDEP & $\begin{array}{r}-0.0191^{*} \\
(0.0716)\end{array}$ & $\begin{array}{c}0.0288 \\
(0.2301)\end{array}$ & $\begin{array}{l}-0.0162^{* * *} \\
(0.0054)\end{array}$ & $\begin{array}{c}0.0011 \\
(0.9232)\end{array}$ \\
\hline CVC & $\begin{array}{l}0.0006 \\
(0.9660)\end{array}$ & $\begin{array}{l}0.0688^{* *} \\
(0.0490)\end{array}$ & $\begin{array}{l}-0.0438^{* * *} \\
(0.0090)\end{array}$ & $\begin{array}{c}0.0237 \\
(0.3320)\end{array}$ \\
\hline GOVT & $\begin{array}{l}-0.8812^{\star * *} \\
(0.0000)\end{array}$ & $\begin{array}{l}0.5645^{\text {*** }} \\
(0.0000)\end{array}$ & $\begin{array}{l}0.0363^{* * *} \\
(0.0017)\end{array}$ & $\begin{array}{c}0.0586 \\
(0.1730)\end{array}$ \\
\hline DIST & $\begin{array}{l}0.0000^{\star \star \star *} \\
(0.0007)\end{array}$ & $\begin{array}{l}-0.0000 \\
(0.1047)\end{array}$ & $\begin{array}{l}0.0000 \\
(0.3786)\end{array}$ & $\begin{array}{r}0.0000^{\star} \\
(0.0947)\end{array}$ \\
\hline $\begin{array}{l}\text { Industry fixed effects } \\
\text { Time fixed effects }\end{array}$ & $\begin{array}{l}\text { Yes } \\
\text { Yes }\end{array}$ & $\begin{array}{l}\text { Yes } \\
\text { Yes }\end{array}$ & $\begin{array}{l}\text { Yes } \\
\text { Yes }\end{array}$ & $\begin{array}{l}\text { Yes } \\
\text { Yes }\end{array}$ \\
\hline $\begin{array}{l}N \\
\chi^{2} \\
\end{array}$ & \multicolumn{4}{|c|}{$\begin{array}{c}6,269 \\
35,833.72\end{array}$} \\
\hline
\end{tabular}

(because space does not allow me to report the results of these robustness tests in full), I do not find any indication of a positive relation between VL and success. Some of the models do not converge. In the models that do converge, VL always has a negative sign, although in some cases without statistical significance. My results are also robust to excluding nonexits from the sample. All in all, I conclude that VL is not associated with better outcomes.

\section{Summary and Conclusion}

In this article, I investigate VL, an important but underexplored source of entrepreneurial finance. In the first part, I use a theoretical model to examine the factors that affect whether an early-stage $\mathrm{VC}$ investor chooses to syndicate with a $\mathrm{VC}$ or a VL investor in the late stage. My model predicts that VL is not a viable alternative under perfect information. However, when information is asymmetric and potential partners do not know the company's quality, although the early-stage 
VC investor does, VL becomes attractive as a signal. Late-stage VC financing is rarely used as a signal. If it is used, it tends to result in a pooling equilibrium.

More precisely, I find that early-stage VC investors that finance companies with higher liquidation value and lower upside potential rely on VL in the late stage and signal the company type. VC financing without signaling is more likely to occur when there are few low-quality companies in the population, so that high-quality companies are less likely to suffer from the negative effects that the presence of the low-quality companies causes. I also find that $\mathrm{VC}$ financing is used more frequently when the uncertainty regarding the final outcome increases and when companies have a high upside potential. Finally, when a company can profit from a late-stage $\mathrm{VC}$ investor value added, the early-stage $\mathrm{VC}$ investor usually turns to another VC investor instead of a VL investor.

My findings shed light on the emerging VL industry and lead to several testable predictions about the criteria by which early-stage VC investors choose between VC and VL in the later stage, and about the relation between the choice of financing and a company's prospects for success. In the second part of my article, I conduct an empirical analysis to test these predictions. My results, which are based on data drawn from a large sample of VC-backed companies in the United States, support these predictions.

I believe that my article opens up promising opportunities for future research. My model could be extended to include a dynamic component to examine how VC investors and VL interact and build their networks of relationships and how these networks may influence the financing choices and success of entrepreneurial companies. Another potential extension could involve including risk preferences of different types of investors, in contrast to my model, which relies on the assumption of risk neutrality among all parties. Future studies may also investigate the economic effects that VL has on the provision of capital to early-stage entrepreneurial companies, a question I touch on only briefly. Last but not least, given that many governments around the world are aware of the inefficiencies that exist in start-up financing and are looking for ways to improve the financing conditions for entrepreneurial companies, the findings of this article and further research in this area may have important consequences for the design of public policies for the emerging VL industry.

\section{Appendix A. Early-Stage VC Investor Expected Payoffs with a Low-Quality Company under Perfect Information}

In the following section, I derive the expected payoffs for early-stage VC investors that finance a low-quality company. If a VC investor cofinances the company in the late stage, this investor obtains a fraction $\alpha$ in return for the investment. This investor payoff thus amounts to

- $\alpha h$ in the high state, and

- $\alpha l$ in the low state.

Given my model setting, the expected value of this payoff must equal the invested sum of 1 unit, that is, $(1-p) \alpha h+p \alpha l=1$, resulting in $\alpha=1 /((1-p) h+p l)$. This leaves the early-stage VC investor with $p l+(1-p) h-1<l$. 
If a VL investor cofinances the company in the late stage, this investor obtains a promised interest $i$ in return for the investment. Thus, this investor payoff is

- $1+i$ in the high state, and

- $l$ in the low state.

Again, the expected value of this payoff must equal the invested sum of 1 unit, that is, $(1-p)(1+i)+p l=1$, resulting in $i=p(1-l) /(1-p)$. This leaves the early-stage VC investor with $p \times 0+(1-p)(h-(1+p(1-l) /(1-p))$, that is, $p l+(1-p) h-1<l$.

Thus, an early-stage VC investor financing a low-quality company prefers liquidation.

\section{Appendix B. Early-Stage VC Investor Expected Payoffs under Asymmetric Information}

If

$$
\frac{h p-h-l p+l}{h p-h-l p} \quad>\quad \frac{1}{h((\lambda k+\lambda-1) p-\lambda+1)+l(-2 \lambda p+p+\lambda)},
$$

then early-stage $\mathrm{VC}$ investors financing high-quality companies prefer $\mathrm{VC}$ pooling to $\mathrm{VC}$ separation, and their expected revenue (with VC pooling) is

with

$$
\begin{aligned}
\mathrm{RVC}_{g, \mathrm{POOL}} & =\left(1-a_{\mathrm{POOL}}\right)(h k p+l(1-p)) \\
a_{\mathrm{POOL}} & =\frac{1}{h((\lambda k+\lambda-1) p-\lambda+1)+l(-2 \lambda p+p+\lambda)} \\
\mathrm{RVC}_{g, \mathrm{POOL}} & =(h k p+l(-p)+l) \\
& \times\left(1-\frac{1}{h((\lambda k+\lambda-1) p-\lambda+1)+l(-2 \lambda p+p+\lambda)}\right)
\end{aligned}
$$

In this case, early-stage VC investors financing a low-quality company expect to obtain

$$
\begin{aligned}
\mathrm{RVC}_{b, \mathrm{POOL}}= & \left(1-a_{\mathrm{POOL}}\right)(l p+h(1-p)) \\
\mathrm{RVC}_{b, \mathrm{POOL}}= & (h(-p)+h+l p) \\
& \times\left(1-\frac{1}{h((\lambda k+\lambda-1) p-\lambda+1)+l(-2 \lambda p+p+\lambda)}\right) .
\end{aligned}
$$

If

$$
\frac{h p-h-l p+l}{h p-h-l p} \leq \frac{1}{h((\lambda k+\lambda-1) p-\lambda+1)+l(-2 \lambda p+p+\lambda)},
$$

then early-stage VC investors financing high-quality companies prefer VC separation to $\mathrm{VC}$ pooling. In this case, their expected revenue is

with

$$
\begin{aligned}
\mathrm{RVC}_{g, \mathrm{SEP}} & =\left(1-a_{\mathrm{SEP}}\right)(h k p+l(1-p)) \\
a_{\mathrm{SEP}} & =\frac{h p-h-l p+l}{h p-h-l p} \\
\mathrm{RVC}_{g, \mathrm{SEP}} & =\frac{l(h k p+l(-p)+l)}{h(-p)+h+l p}
\end{aligned}
$$


Early-stage VC investors financing a low-quality company do not prefer mimicking the high-quality company to liquidation, because they do not obtain a higher expected revenue

If

$$
\begin{aligned}
& \mathrm{RVC}_{b, \mathrm{SEP}}=\left(1-a_{\mathrm{SEP}}\right)(l p+h(1-p)), \\
& \mathrm{RVC}_{b, \mathrm{SEP}}=\left(1-\frac{h p-h-l p+l}{h p-h-l p}\right)(l p+h(1-p)), \\
& \mathrm{RVC}_{b, \mathrm{SEP}}=l . \\
& \frac{p-l p+\lambda-l \lambda-2 p \lambda+2 l p \lambda}{1-p-\lambda+2 p \lambda}<h-1-\frac{l}{1-p},
\end{aligned}
$$

then early-stage VC investors financing high-quality companies prefer VL pooling to VL separation, and their expected revenue with VL pooling amounts to

with

$$
\begin{aligned}
\mathrm{RVL}_{g, \mathrm{POOL}} & =p\left(h-\left(1+i_{\mathrm{POOL}}\right)\right) \\
i_{\mathrm{POOL}} & =\frac{l(-p)+2 \lambda l p-\lambda l+p-2 \lambda p+\lambda}{2 \lambda p-p-\lambda+1} \\
\mathrm{RVL}_{g, \mathrm{POOL}} & =\frac{p(h((2 \lambda-1) p-\lambda+1)+l(-2 \lambda p+p+\lambda)-1)}{(2 \lambda-1) p-\lambda+1} .
\end{aligned}
$$
obtain

In this case, early-stage $\mathrm{VC}$ investors financing a low-quality company expect to

$$
\begin{aligned}
& \mathrm{RVL}_{b, \mathrm{POOL}}=(1-p)\left(h-\left(1+i_{\mathrm{POOL}}\right)\right), \\
& \mathrm{RVL}_{b, \mathrm{POOL}}=\frac{(1-p)(h((2 \lambda-1) p-\lambda+1)+l(-2 \lambda p+p+\lambda)-1)}{(2 \lambda-1) p-\lambda+1} . \\
& \text { If } \quad \frac{p-l p+\lambda-l \lambda-2 p \lambda+2 l p \lambda}{1-p-\lambda+2 p \lambda} \geq h-1-\frac{l}{1-p},
\end{aligned}
$$

then early-stage VC investors financing high-quality companies prefer VL separation to VL pooling, and their expected revenue with VL separation is

with

$$
\begin{aligned}
\mathrm{RVL}_{g, \mathrm{SEP}} & =p\left(h-\left(1+i_{\mathrm{SEP}}\right)\right), \\
i_{\mathrm{SEP}} & =h-\frac{l}{1-p}-1, \\
\mathrm{RVL}_{g, \mathrm{SEP}} & =\frac{l p}{1-p} .
\end{aligned}
$$

Early-stage VC investors financing a low-quality company do not prefer mimicking the high-quality company to liquidation, because they do not obtain a higher expected revenue

$$
\begin{aligned}
& \operatorname{RVL}_{b, \mathrm{SEP}}=(1-p)\left(h-\left(1+i_{\mathrm{SEP}}\right)\right), \\
& \operatorname{RVL}_{b, \mathrm{SEP}}=(1-p)\left(h-\left(1+h-\frac{l}{1-p}-1\right)\right), \\
& \operatorname{RVL}_{b, \mathrm{SEP}}=l .
\end{aligned}
$$




\section{Appendix C. Variable Definitions}

\section{Market Characteristics}

IND_BETA: Industry beta. Calculated on the basis of the S\&P industry index returns over the 125 trading days preceding the financing round. Source: S\&P Capital IQ database.

FRAC_G: Proportion of high-quality companies in the current population. Calculated as the success rate of VC-backed companies in the following year. Source: Dow Jones Venture Source database.

VC: Amount of annual fund commitments to the U.S. VC industry in US\$ billions. Source: NVCA, 2014.

\section{Company Characteristics}

VL: A binary variable that equals 1 if the company obtains venture lending, and 0 otherwise. Source: Dow Jones Venture Source database.

AGE: Company age in days. Source: Dow Jones Venture Source database.

CALIF: A binary variable that equals 1 if the company has its headquarters in California at the time of the investment, and 0 otherwise. Source: Dow Jones Venture Source database.

MAS: A binary variable that equals 1 if the company has its headquarters in Massachusetts at the time of the investment, and 0 otherwise. Source: Dow Jones Venture Source database.

NY: A binary variable that equals 1 if the company has its headquarters in New York at the time of the investment, and 0 otherwise. Source: Dow Jones Venture Source database.

PEN: A binary variable that equals 1 if the company has its headquarters in Pennsylvania at the time of the investment, and 0 otherwise. Source: Dow Jones Venture Source database.

TEX: A binary variable that equals 1 if the company has its headquarters in Texas at the time of the investment, and 0 otherwise. Source: Dow Jones Venture Source database.

NUM_OF_INV: Number of investors in the company. Source: Dow Jones Venture Source database.

PPE_TA: Ratio of property, plant, and equipment to total assets. Source: Bureau van Dijk Orbis database.

FA_TA: Ratio of fixed assets to total assets. Source: Bureau van Dijk Orbis database.

TANG_TA: Ratio of tangible assets to total assets. Source: Bureau van Dijk Orbis database.

\section{VC Firm Characteristics}

RANK: This variable reflects the rank of the best-ranked VC that financed this company in the prior rounds. The data are drawn from the Lee-Pollock-Jin VC Reputation Index, a time-varying index of formative indicators of $\mathrm{VC}$ firm reputation, which covers more than 1,000 VC firms in the relevant years. Source: Lee et al. (2011), http://www.timothypollock.com/vc_reputation.htm.

VC_AGE: The age of the lead VC firm involved in the last round. Source: Dow Jones Venture Source database.

INDEP: A binary variable that equals 1 if the lead VC firm involved in the last round is independent (noncaptive), and 0 otherwise. Source: Dow Jones Venture Source database, Thomson ONE database, VC firms' Web sites.

CVC: A binary variable that equals 1 if the last-round lead VC is corporate, and 0 otherwise. Source: Dow Jones Venture Source database, Thomson ONE database, VC firms' Web sites. 
GOVT: A binary variable that equals 1 if the last-round lead VC is a government VC firm, and 0 otherwise. Source: Dow Jones Venture Source database, Thomson ONE database, VC firms' Web sites.

DIST: The geographical distance between the VC firm and the company in miles. I convert the address of the lead VC involved in the last round and the company address at the time of the investment into latitude-longitude coordinate pairs. To calculate the distance, I use the Vincenty formula for geodesic distances between a pair of points on Earth's surface using an accurate ellipsoidal model of Earth. Source: Dow Jones Venture Source database, Google Maps Geocoding API, Vincenty (1975).

\section{VC Fund Characteristics}

LFS: The size of the lead VC fund involved in the last round (in US\$ billions). For nonU.S. funds, I use historical exchange rates for the conversion. Source: Dow Jones Venture Source database, Thomson Datastream, Oanda.

LFS $^{2}$ : The squared size of the lead VC fund involved in the last round (in US\$ billions). For non-U.S. funds, I use historical exchange rates for the conversion. Source: Dow Jones Venture Source database, Thomson Datastream, Oanda.

\section{References}

Admati, A. R., and P. Pfleiderer. "Robust Financial Contracting and the Role of Venture Capitalists." Journal of Finance, 49 (1994), 371-402.

Amornsiripanitch, N.; P. A. Gompers; and Y. Xuan. "More Than Money: Venture Capitalists on Boards." Available at http://dx.doi.org/10.2139/ssrn.2586592 (2016).

Barry, C. B. "New Directions in Research on Venture Capital Finance." Financial Management, 23 (1994), 3-15.

Bergemann, D., and U. Hege. "Venture Capital Finance, Moral Hazard, and Learning." Journal of Banking and Finance, 22 (1998), 703-735.

Bottazzi, L.; M. Da Rin; and T. Hellmann. "Who Are the Active Investors? Evidence from Venture Capital." Journal of Financial Economics, 89 (2008), 488-512.

Brander, J. A.; R. Amit; and W. Antweiler. "Venture Capital Syndication: Improved Venture Selection versus Value-Added Hypothesis." Journal of Economics and Management Strategy, 11 (2002), $423-452$.

Brav, O. "Access to Capital, Capital Structure, and the Funding of the Firm." Journal of Finance, 64 (2009), 263-308.

British Private Equity and Venture Capital Association. The Rise of Venture Debt in Europe. London, UK: British Private Equity and Venture Capital Association (2010).

Casamatta, C. "Financing and Advising: Optimal Financial Contracts with Venture Capitalists." Journal of Finance, 58 (2003), 2059-2086.

Cho, I.-K., and D. M. Kreps. "Signaling Games and Stable Equilibria." Quarterly Journal of Economics, 102 (1987), 179-221.

Cosh, A.; D. J. Cumming; and C. Hughes. "Outside Enterpreneurial Capital." Economic Journal, 119 (2009), 1494-1533.

Cox, D. R. "Regression Models and Life-Tables." Journal of the Royal Statistical Society, Series B, 34 (1972), 187-220.

Crawford, D. Smartcard Systems, Inc. Darden Case UVA-F-1405. Charlottesville, VA: Darden Business Publishing (2003).

Cumming, D. J. "Capital Structure in Venture Finance." Journal of Corporate Finance, 11 (2005), $550-585$.

Cumming, D. J. "Adverse Selection and Capital Structure: Evidence from Venture Capital." Entrepreneurship Theory and Practice, 30 (2006), 155-184.

Cumming, D. J. "Contracts and Exits in Venture Capital Finance." Review of Financial Studies, 21 (2008), 1947-1982.

Cumming, D. J., and N. Dai. "Local Bias in Venture Capital Investments." Journal of Empirical Finance, 17 (2010), 362-380.

Cumming, D. J., and N. Dai. "Fund Size, Limited Attention and Valuation of Venture Capital Backed Firms." Journal of Empirical Finance, 18 (2011), 2-15. 
Cumming, D. J.; B. Haslem; and A. Knill. "Entrepreneurial Litigation and Venture Capital Finance." Journal of Financial and Quantitative Analysis, forthcoming (2017).

Cumming, D. J., and S. Johan. "Information Asymmetries, Agency Costs and Venture Capital Exit Outcomes." Venture Capital: An International Journal of Entrepreneurial Finance, 10 (2008a), 197-231.

Cumming, D. J., and S. Johan. "Preplanned Exit Strategies in Venture Capital." European Economic Review, 52 (2008b), 1209-1241.

Cumming, D. J., and S. Johan. "Venture Capital Investment Duration." Journal of Small Business Management, 48 (2010), 228-257.

De Bettignies, J. E., and J. A. Brander. "Financing Entrepreneurship: Bank Finance versus Venture Capital." Journal of Business Venturing, 22 (2007), 808-832.

Fine, J., and R. Gray. "A Proportional Hazards Model for the Subdistribution of a Competing Risk." Journal of the American Statistical Association, 94 (1999), 496-509.

Fischer, T., and G. de Rassenfosse. "Venture Debt Financing: Determinants of the Lending Decision." Available at http://dx.doi.org/10.2139/ssrn.1909602 (2013).

Fluck, Z.; K. Garrison; and S. Myers. "Venture Capital Contracting and Syndication: An Experiment in Computational Corporate Finance." Working Paper No. 11624, National Bureau of Economic Research (2005).

Gordan, P. "Venture Debt: A Capital Idea for Startups.” Kauffman Fellows Report, 4 (2012).

Hall, R. E., and S. E. Woodward. "The Burden of the Nondiversifiable Risk of Entrepreneurship." American Economic Review, 100 (2010), 1163-1194.

Hardymon, G. F., and A. Leamon. Silicon Valley Bank. HBS Case 9-800-332. Boston, MA: Harvard Business School Publishing (2001).

Hardymon, G. F.; J. Lerner; and A. Leamon. Gold Hill Venture Lending. HBS Case 804-083. Boston, MA: Harvard Business School Publishing (2005).

Harris, M., and A. Raviv. "Capital Structure and the Informational Role of Debt." Journal of Finance, 45 (1990), 321-349.

Harris, M., and A. Raviv. “The Theory of Capital Structure.” Journal of Finance, 46 (1991), 297-355.

Hartmann-Wendels, T.; G. Keienburg; and S. Sievers. "Adverse Selection, Investor Experience and Security Choice in Venture Capital Finance: Evidence from Germany." European Financial Management, 17 (2011), 464-499.

Hellmann, T., and M. Puri. "Venture Capital and the Professionalization of Start-Up Firms: Empirical Evidence." Journal of Finance, 57 (2002), 169-197.

Hochberg, Y.; A. Ljungqvist; and Y. Lu. "Whom You Know Matters: Venture Capital Networks and Investment Performance." Journal of Finance, 62 (2007), 251-301.

Ibrahim, D. M. “Debt as Venture Capital.” University of Illinois Law Review, 2010 (2010), 1169-1210.

Jensen, M. C. "Agency Costs of Free Cash Flow, Corporate Finance, and Takeovers." American Economic Review, 76 (1986), 323-329.

Jensen, M. C., and W. H. Meckling. "Theory of the Firm: Managerial Behavior, Agency Costs and Ownership Structure.” Journal of Financial Economics, 3 (1976), 305-360.

Kaplan, S. N., and P. Strömberg. "Financial Contracting Theory Meets the Real World: An Empirical Analysis of Venture Capital Contracts." Review of Economic Studies, 70 (2003), 281-315.

Lee, P. M.; T. G. Pollock; and K. Jin. "The Contingent Value of Venture Capitalist Reputation for Entrepreneurial Firms.” Strategic Organization, 9 (2011), 33-69.

Lemmon, M. L., and J. F. Zender. "Debt Capacity and Tests of Capital Structure Theories." Journal of Financial and Quantitative Analysis, 45 (2010), 1161-1187.

Manigart, S.; A. Lockett; M. Meuleman; M. Wright; H. Landstroem; H. Bruining; P. Desbrieres; and U. Hommel. "Venture Capitalists' Decision to Syndicate." Entrepreneurship Theory and Practice, 30 (2006), 131-153.

Myers, S. C., and N. S. Majluf. "Corporate Financing and Investment Decisions When Firms Have Information That Investors Do Not Have.” Journal of Financial Economics, 13 (1984), 187-221.

Nahata, R.; S. Hazarika; and K. Tandon. "Success in Global Venture Capital Investing: Do Institutional and Cultural Differences Matter?” Journal of Financial and Quantitative Analysis, 49 (2014), 1039-1070.

National Venture Capital Association. 2014 NVCA Yearbook. Washington, DC: National Venture Capital Association (2010).

Rajan, R., and L. Zingales. "What Do We Know about Capital Structure? Some Evidence from International Data." Journal of Finance, 50 (1995), 1421-1460.

Robb, A. M., and D. T. Robinson. "The Capital Structure Decisions of New Firms." Review of Financial Studies, 27 (2014), 153-179.

Roberts, M.; W. A. Sahlman; and L. Kind. Pinnacle Ventures. HBS Case 9-808-048. Boston, MA: Harvard Business School Publishing (2008). 
Sahlman, W. A. "The Structure and Governance of Venture-Capital Organizations." Journal of Financial Economics, 27 (1990), 473-521.

Schmidt, K. M. "Convertible Securities and Venture Capital Finance.” Journal of Finance, 58 (2003), 1139-1166.

Schwienbacher, A. "The Entrepreneur's Investor Choice: The Impact on Later-Stage Firm Development." Journal of Business Venturing, 28 (2013), 528-545.

Stulz, R. "Managerial Discretion and Optimal Financing Policies." Journal of Financial Economics, 26 (1990), 3-27.

Vincenty, T. "Direct and Inverse Solutions of Geodesics on the Ellipsoid with Application of Nested Equations." Survey Review, 23 (1975), 88-93.

Winton, A., and V. Yerramilli. "Entrepreneurial Finance: Banks versus Venture Capital." Journal of Financial Economics, 88 (2008), 51-79. 